University of Nebraska - Lincoln

DigitalCommons@University of Nebraska - Lincoln

2003

\title{
THE RIGHT TO EDUCATION UNDER THE SOUTH AFRICAN CONSTITUTION
}

\author{
Eric Berger \\ University of Nebraska College of Law, eric.berger@unl.edu
}

Follow this and additional works at: https://digitalcommons.unl.edu/lawfacpub

Part of the Legal Studies Commons

Berger, Eric, "THE RIGHT TO EDUCATION UNDER THE SOUTH AFRICAN CONSTITUTION" (2003). College of Law, Faculty Publications. 26.

https://digitalcommons.unl.edu/lawfacpub/26

This Article is brought to you for free and open access by the Law, College of at DigitalCommons@University of Nebraska - Lincoln. It has been accepted for inclusion in College of Law, Faculty Publications by an authorized administrator of DigitalCommons@University of Nebraska - Lincoln. 


\title{
NOTES
}

\section{THE RIGHT TO EDUCATION \\ UNDER THE SOUTH AFRICAN CONSTITUTION}

\author{
Eric Berger
}

The South African Constitution epitomizes a new breed of modern constitution, enshrining socioeconomic rights rather than only "negative" liberties. Among these is the right to education. However, despite the Constitution's progressive values, many South African schools remain inadequate. This Note argues that, given the opportunity, the South African Constitutional Court should hold the current educational system unconstitutional as applied to the worst schools. Constitutional text, purpose, and precedent, indeed, mandate this outcome. Moreover, vindicating the constitutional right to education will help South Africa attain other social and economic goals. However, in keeping with its other socioeconomic rights cases, the Court must carefully craft its decision so as not to offend separation-of-powers principles. The Court must thus provide the legislature enough flexibility to consider budgetary and other constraints while ultimately protecting education's vital role in a healthy democracy.

\section{INTRODUCTION}

That education is fundamental to a well-functioning democracy has been long accepted. Thomas Jefferson well articulated the connection between education and democracy, arguing that to render democratic governments safe, the people's "minds must be improved to a certain degree" and that therefore "[a]n amendment of our [Virginia] constitution must here come in aid of the public education." And yet, despite their generally acknowledged importance, schools frequently fail to receive the resources necessary to improve.

Nowhere is this paradox more evident than contemporary South Africa, where the country has included the right to education in its emphatically modern Constitution, ${ }^{2}$ but where schools, particularly for poor blacks, remain woefully inadequate. The explanation for these shortcomings is obvious-the nation simply lacks the resources to address all its citizens' needs - and yet the consequences are significant. Even after the fall of apartheid, South Africa is the world's third most economically unequal country. ${ }^{3}$ If South Africa is to become an "open and democratic

1. Thomas Jefferson, Notes on the State of Virginia 148 (William Peden ed., Univ. of N.C. Press 1955) (1787).

2. All references to the South African Constitution refer to the 1996 Constitution, as opposed to the interim constitution it replaced.

3. See Viviene Taylor, United Nations Development Programme, Transformation for Human Development: South Africa 64 (Susan de Villiers ed., 2000) (ranking Brazil, 
society based on human dignity, equality and freedom," ${ }^{4}$ its education system must work to remedy the country's stark inequalities by providing all students the skills and experiences necessary to participate productively in such a society. Given the right to education established in section 29 of the Constitution and the Constitutional Court's recent attention to other socioeconomic rights, ${ }^{5}$ unhappy parents might consider launching a claim that the government's current system of education is inadequate.

This Note argues that should such a case arise, the Constitutional Court should find that the South African Constitution requires the government to provide an adequate education and that therefore the current educational system is unconstitutional as applied to the worst schools. However, balancing socioeconomic rights with economic limitations is no easy task. Thus, this Note also explores education's place within that intractable problem and the South African Court's role in expounding the country's aspirational constitution. Ultimately, it concludes that protecting vulnerable groups' constitutional right to education will, in the long run, help South Africa attain its other constitutional, social, and economic goals, but that the Court, in keeping with its other socioeconomic rights decisions, must craft its decision so as not to offend separation-of-powers principles.

Part I details the current state of education in South African schools, focusing on conditions in some of the country's most disadvantaged communities where facilities and student achievement are poor, especially compared to the nation's wealthier schools. Part II applies the constitutional right to education to this school system. Section 29 of the Constitution establishes the right to basic and further education. It does not articulate a specific standard of education, but this Note argues that the standard must be "adequate," high enough to satisfy the democratic and civic ideals articulated in section 39, which provides courts with an interpretive framework for the Bill of Rights. Given this standard, then, the Court should find the worst schools' conditions unconstitutional under section 29 and section 9's equal protection provisions, even though the nation's limited resources make it difficult to comply entirely with the Constitution's requirements. Part III argues that the Court should define "adequacy" by exploring schools' crucial roles in well-functioning democ-

Guatemala, and South Africa as the three most unequal societies in the world as measured by the Gini coefficient); see also Arthur Chaskalson, Dialogue: Equality \& Dignity in South Africa, 5 Green Bag 2d 189, 189 (2002) (noting that three centuries of colonialism and fifty years of apartheid "created a society with huge disparities-disparities of wealth, of privilege, of opportunities, of skills").

4. S. Afr. Const. ch. 2 (Bill of Rights), $\S 39(1)(\mathrm{a})$.

5. See, e.g., Minister of Health v. Treatment Action Campaign, 2002 (5) SA 721 (CC) (holding that government must make every effort to include in HIV education and treatment program everybody for whonı treatment could combat mother-to-child transmission of HIV); Gov't of Rep. of S. Afr. v. Grootboom, 2001 (1) SA 46 (CC) (holding that government had obligation to make housing progressively available). 
racies and that improved education will also help the nation address other social problems. Indeed, democratic theories of education, which American case law can help elucidate, ought not only inform the Court's definition of adequacy, but can provide broader philosophical and practical justifications for a judicial decision requiring the other government branches to do more to improve schools.

\section{The Quality of Education in South Africa}

Like most injustices in contemporary South Africa, educational inequality can be traced easily back to apartheid. Shortly after the National Party victory in $1948,{ }^{6}$ the architects of apartheid implemented a formalized system of race-based education. Codified in the Bantu Education Act of 1953 and the Extension of University Education Act, national education policy was an integral part of apartheid's dehumanizing segregation. ${ }^{7}$ African ${ }^{8}$ schools were thus designed accordingly, training students in subservience and manual labor. ${ }^{9}$

Decades later, even after the country's first free elections in 1994 and school desegregation, the lingering effects of such policies are visible in poor schooling for students of all ages. ${ }^{10}$ A recent study shows that South African pupils at age ten are "way behind" those in many other African

6. The National Party represented South Africa's Afrikaner minority and, shortly after its victory, instituted apartheid, thus intensifying and codifying the country's racist, segregationist system. See, e.g., Allister Sparks, The Mind of South Africa 147-213 (1990) (recounting National Party's rise to power after World War II).

7. Id. at 196.

8. This Note uses the adjectives "African" and "black" synonymously, in this case to refer to schools attended by black students. Most South African scholarship also uses these terms interchangeably. It is also important to remember that South African racial groups are hardly confined to blacks and whites but also include other prominent groups, most notably "coloureds" and Indians. See, e.g., id. at 72-90. To highlight the educational inequalities in South Africa, however, this Note will focus on the differences between primarily black and primarily white schools.

9. Alfreda A. Sellers Diamond, Constitutional Comparisons and Converging Histories: Historical Developments in Equal Educational Opportunity Under the Fourteenth Amendment of the United States Constitution and the New South African Constitution, 26 Hastings Const. L.Q. 853, 873 (1999). The apartheid government also sought to emphasize existing power structures by requiring all students to learn Afrikaans, the language of oppression. Opposition to this policy sparked the 1976 Soweto riots. See, e.g., Sparks, supra note 6, at 301 (noting that "enforced use of the Afrikaans language in black schools was the detonator that set off the eruption" in Soweto). See generally William Finnegan, Crossing the Line: A Year in the Land of Apartheid (1994) (recounting year teaching in Cape Town township school during apartheid).

10. See Paul Taylor, South Africa Quietly Integrates Schools, Wash. Post, Jan. 29, 1995, at Al (noting that the first attempt at forced desegregation was remarkably peaceful but that few white schools have become more than fifteen or twenty percent black). The South African Constitution distinguishes between "basic" education (up to tenth grade) and "further" education (tenth grade and beyond). See infra Parts II.A, II.B.2. The discussion here will not separate the analysis of basic and further education into separate categories, because many of the relevant statistics reflect patterns in entire school districts which include all grade levels and therefore both basic and further education. 
countries, such as Botswana and Madagascar. ${ }^{11}$ Nowhere are the inadequacies more evident than in predominantly black areas; apartheid's impact on the education of African children, particularly in the rural "homelands," 12 remains severe. ${ }^{13}$ As Minister of Education Kader Asmal grimly acknowledged, "South Africa is two nations, poor and rich. After apartheid, when this two nation status is no longer kept in place by violence but by the workings of inertia and of continuing privilege, the higher education system, in large measure, continues to reproduce the inequities of the past." 14

lndeed, a number of factors conspire to make poor schools hard to improve. Perhaps most important, recent government economic policies, as reflected in the 1998 Growth, Employment and Redistribution Programme (GEAR), have begun to prioritize fiscal discipline rather than social redress, designing policies to achieve low inflation rates and debt control. ${ }^{15}$ The government has thus begun to decentralize and privatize many social benefits, including education. ${ }^{16}$ Not surprisingly, government educational expenditures have decreased noticeably, ${ }^{17}$ and it is the poorest schools that have been hardest hit.

11. Karen MacGregor, Analysis at Age 10 Reveals Failure, Times (London), Sept. 1, 2000, Educ. Supp., at 10. Since many children in Africa leave school at age ten, achievement levels at this age are particularly important. ld.

12. Diamond, supra note 9 , at 901 . Under apartheid, the National Party moved large portions of the African population into small, rural areas, causing overpopulation and profoundly disrupting more than half a million lives. The government claimed that these "homelands" were in fact independent nations and that the black and white populations were each better off with this "separate but equal" arrangement. Of course, artificially devised and forcefully realized, these homelands, cut off from the outside world, more resembled "resettlement camps." They were far from equal and suffered years of dire poverty and disease. Sparks, supra note 6, at 202-05.

13. Despite its best intentions, the early post-apartheid governments had little money to throw at inadequate black schools. Thus, "dilapidated schools, unqualified teachers, overcrowded classrooms, poor discipline and a culture of protest . . . continued to bedevil black education." Taylor, supra note 10. Indeed, since school funding blends public and private funding, the richer white schools that enjoyed preferred governmental treatment under apartheid still tend to be better funded. See International Development Network, RTI Offers Course in Applied Education Economics in South Africa (Apr. 8, 1999), at http://www.idn.org/members/org/rti/rti040899-4.htm (on file with the Columbia Law Review).

14. Kader Asmal, Minister of Education, Address at the Media Launch of the National Plan for Higher Education (Mar. 5, 2001), available at http://education.pwv.gov.za/ Media/Speeches_2001/March01/Nat_Plan_HE.htm (on file with the Columbia Law Review). As the statistics here demonstrate, the inequities to which Asmal refers apply also to basic education.

15. Sophie Oldfield, The South African State in Transition: A Question of Form, Function, and Fragmentation, in The State, Education, and Equity in Post-Apartheid South Africa 32, 43 (Enver Motala \& John Pampallis eds., 2002) [hereinafter Motala \& Pampallis].

16. Katerina Nicolaou, The Link Between Macroeconomic Policies, Education Policies and the Education Budget, in Motala \& Pampallis, supra note 15, at 53, 89.

17. E.g., Oldfield, supra note 15 , at 43 . 
Budget reductions compound a number of difficulties poor schools already face. For instance, most schools, even in the poorest areas, charge "users' fees" to all parents; ${ }^{18}$ budget cuts force schools to rely even more on these fees to provide an education. Many poor parents have difficulty paying these fees, meaning either that their children do not receive an education or that the schools do not receive adequate funding to instruct their students. Not surprisingly, these "tuition" requirements perpetuate the very inequalities that education theoretically would help the nation overcome. ${ }^{19}$

Providing underprivileged schools with a qualified faculty presents another major challenge. Good teachers tend to prefer staying in better schools, and even those who might be inclined to help a poorer school might find the logistics of moving prohibitively difficult. ${ }^{20}$ The government policy of strict fiscal discipline further exacerbated the teacher shortage in poor schools when the state offered its teachers voluntary severance packages, which led to the retirement of many of the most experienced and most qualified teachers. ${ }^{21}$ To compound the problem, the higher education system for training teachers has also suffered recent cutbacks, resulting in fewer trained teachers to replace those who opted for early retirement. ${ }^{22}$ Rich communities can compensate by voting to hire extra teachers and offering higher salaries to recruit the most qualified instructors, but poor schools are left to rely on government funding. ${ }^{23}$ This funding is, in theory, equal between rich and poor schools,

18. E.g., Salim Vally \& Yolesa Dalamba, S. Afr. Hum. Rts. Comm'n, Racism, Racial Integration and Desegregation in South African Public Secondary Schools 47 (1999); Daria Roithmayr, Locked in Inequality: Discrimination as an Emergent Phenomenon, Persp. in Educ. (S. Afr.) (forthcoming 2003) [hereinafter Roithmayr, Locked in Inequality].

19. E.g., Roithmayr, Locked in Inequality, supra note 18, at 1 . See generally Daria Roithmayr, The Constitutionality of School Fees in Public Education, 19 S. Afr. J. Hum. Rts. (forthcoming 2003) [hereinafter Roithmayr, Constitutionality of School Fees] (questioning constitutionality of such fees). But see Department of Education (S. Afr.), Report to the Minister: A Review of the Financing, Resourcing, and Costs of Education in Public Schools 81 (March 3, 2003), available at http://education.pwv.gov.za [hereinafter Report to Minister] (explaining that the poorest parents can apply for exemptions from school fees).

20. See, e.g., Luis Crouch, Educational Spending Inequality in South Africa: Some Key Issues and Quantitative Dimensions, Talking Points Prepared for Colleagues at Department of Education (S. Afr.) (June 2000) (on file with the Columbia Law Review) [hereinafter Crouch, Inequality] (noting difficulty of reallocating high-quality educators). Crouch, former economic consultant to the national Department of Education in Pretoria, argues that these systematic problems make it extremely difficult for poor schools to catch up to wealthier ones. Id.

21. Oldfield, supra note 15 , at 44 . See generally Salim Vally \& Console Tleane, The Rationalisation of Teachers and the Quest for Social Justice in Education in an Age of Fiscal Austerity, in Motala \& Pampallis, supra note 15, at 178 (discussing fiscal constraints on policies designed to redistribute teachers to poorer schools).

22. Oldfield, supra note 15 , at 44 .

23. See, e.g., id. ("schools with a wealthy parent body utilise fees to maintain their privilege and standard of education relative to predominantly black schools that are already disadvantaged"). This is one similarity between South African and American 
but the broader policy trend towards privatization has created even greater inequalities, as it forces communities to rely more heavily on nongovernmental money.

Similarly, poor schools began with inferior facilities and supplies and at current funding rates will not be able to catch up. ${ }^{24}$ Once again, this problem exacerbates preexisting inequalities. Because poor children tend to have less exposure to the letters of the alphabet at an early age, they are inherently harder and more expensive to teach. ${ }^{25}$ Without additional funding to provide remedial literacy training and materials, schools in poor neighborhoods will be unlikely to overcome the educational obstacles inherent in poverty. ${ }^{26}$ lndeed, such concerns suggest that the poorer schools need significantly more funding than richer schools if education is truly to benefit all South Africans.

Given the difficulties facing many South African schools and the government's reluctance to provide the funding to address them, ${ }^{27}$ it is not surprising that their facilities and achievement rates are poor. Statistics are an incomplete measure of educational quality, but they do paint a general picture of a school district's needs. Even after the African National Congress (ANC) government came to power, black education remained vastly inferior to white education, ${ }^{28}$ despite the fact that educational equity became a basic principle of the budget strategy. ${ }^{29}$ Recent studies show that pupil-to-teacher ratios in the Eastern Cape, Northern Province, and Mpumalanga, all predominantly black, rural provinces,

education problems. American public school funding, much of which comes from property taxes, also gives big advantages to wealthier school districts. Some state courts have held that the resulting inequities violate state and federal equal protection requirements. See, e.g., Serrano v. Priest, 557 P.2d 929 (Cal. 1976) (holding that California public school financing, which conditioned availability of school revenue on district wealth, violated state constitution's equal protection provisions). For further comparison between American and South African education law, see infra Part 1II.

24. See, e.g., E-mail Interview with Luis Crouch, Former Economic Consultant to the National Department of Education in Pretoria (Sept. 14, 2002) (on file with the Columbia Law Review).

25. Id.

26. See, e.g., id.; Nicolaou, supra note 16, at 103-04 (noting that privatization will result in an even more prominent social schism); see also Report to Minister, supra note 19 , at 17-18 (noting introduction of "pro-poor school" funding in 2000 has sought to bring about more equity in schools but that inequality is still a concern).

27. To be fair, education comprises about $20 \%$ of the national budget. E.g., Nicolaou, supra note 16 , at 71,77 . However, the aforementioned move towards fiscal discipline has shrunk the entire budget, thus decreasing the annual amount spent on education and other government services. Id. at 89.

28. See Mixing up South Africa, Economist, Jan. 25, 1995, at 17, 18 (noting that as of early 1995 South Africa still spent twice as much on white pupils as it did on black pupils).

29. See Department of Education (S. Afr.), White Paper on Education and Training, General Notice 196 of 15 March 1995, Parliament of the Republic of South Africa ch. 11, para. 1(3), at 61 [hereinafter White Paper] (discussing budget reform and funding requirements of the new education system). 
were, respectively, 51 to 1,44 to 1 , and 41 to $1 .^{30}$ By way of contrast, in the Western Cape Province, which is predominantly white, the pupil-toteacher ratio was 25 to $1 .{ }^{31}$ Moreover, the Western Cape has approximately eight teachers per administrator, whereas the Northern Province has thirty, a disparity that not only highlights inequality but also helps explain why poorer schools have so much trouble catching up to wealthier ones: Without clerical and administrative assistance, teachers' chief concerns are day-to-day management, not curricular reform and improvement. ${ }^{32}$

The poorest schools also lack the facilities enjoyed by wealthier communities. As recently as 2000 , over $35 \%$ of all school buildings were in "weak to very weak" condition, ${ }^{33}$ and, of course, buildings needing the most repairs were concentrated in poor, predominantly black, areas. A recent analysis showed approximately one-half of the rural Northern Province's 1.9 million students to have no water within walking distance of their schools. Seventy-nine percent had no toilets, eighty percent no telephones. Forty-one percent of Northern Province homeland schools needed major repairs. ${ }^{34}$ Urban black township schools, which continue to fail as wealthy blacks move out of townships or arrange for their children to commute to predominantly white schools, fared no better, tending to be badly overcrowded and also lacking electricity and telephones. ${ }^{35}$ In the Western Cape, by way of contrast, $90 \%$ of schools had telephones, and only $1 \%$ required major repairs. ${ }^{36}$ These numbers, of course, directly reflect each province's education budget. Whereas the predominantly white Western Cape enjoys the highest per capita expenditure on primary school education, the mostly black Eastern Cape, KwaZulu-Natal, Mpumalanga, and Northern Provinces have the lowest per capita expenditure levels. ${ }^{37}$ Not surprisingly, then, the Western Cape had the lowest

30. Diamond, supra note 9, at 901. Not surprisingly, most inequalities exist along class, rather than racial, lines, so that schooling for poor whites is worse than for wealthy, suburban blacks. However, because so many blacks continue to live in poverty and because whites continue to control much of the country's wealth, it remains generally true that predominantly black schools will be far inferior to predominantly white schools.

31. 1d.

32. Luis Crouch, Fifteen Facts, Two Goals, and Some Likely Stories: The Dilemmas of School Funding in South Africa 3 (Apr. 1997) (unpublished manuscript, on file with the Columbia Law Review) [hereinafter Crouch, Dilemmas].

33. Russell Andrew Wildeman, Infrastructure Provisioning in Schools and the Right to Basic Education 15 (Univ. of Witswatersrand, Ctr. for Applied Legal Studies \& Educ. Pol'y Unit, Educ. Rights Project, lssue Paper No. 2, 2002).

34. Diamond, supra note 9 , at 901 .

35. Violet Madingoane, Hope in the Beloved Country, Times (London), Jan. 7, 2000, Educ. Supp., at 10.

36. Diamond, supra note 9 , at 901 .

37. Department of Education (S. Afr.), Education for All 2000 Assessment (Mar. 2000), available at http://education.pwv.gov.za/DoE_Sites/Quality_Assurance_Folder/ Educ_for_All_Assessment/EFA_Report.htm (on file with the Columbia Law Review) [hereinafter Education for All]. 
percentage of under-qualified teachers $(10.2 \%)$, while the Northwest, Free State, and KwaZulu-Natal Provinces all had over 30\% under-qualified teachers. ${ }^{38}$

Predictably, these gross inequalities in spending, facilities, and faculties have resulted in unequal achievement. Whereas only two of ten African children reach the "matric" year ${ }^{39}$ in their education, eight of ten white children do. ${ }^{40}$ One result is that illiteracy is prevalent in South Africa, and, again, the wealthier white provinces of the Western Cape and Gauteng have the highest literacy rates $(76.4 \%$ and $75.6 \%$ respectively), while the rural, poor, and mostly black Northern Province has the lowest $(58.9 \%){ }^{41}$ Of course, apartheid schools explain why many older people cannot read, but the Department of Education itself also cites poor teaching and lack of access to reading materials as reasons why learner achievement continues to be poor. ${ }^{42}$ lndeed, the failure in the poor communities seems to start during the earliest years. Whereas a large majority of white children proceed smoothly through elementary school, schools have had difficulty retaining black students. A recent study of rural black children showed that only $39 \%$ progressed from second to seventh grade without some disruption. ${ }^{43}$

What is perhaps most disconcerting is the lack of meaningful improvement. As recently as 1999, one-sixth of the nation's schools suffered failure rates of $80 \%$ or more. ${ }^{44}$ Some standards have even decreased:

38. Id. Of course, discrepancies run not only between provinces but within them. The difficulty of moving top-rate teachers to poorer schools, due, in part, to South Africa's rigid labor union structure, makes dealing with intraprovincial inequality a major problem. Crouch, Inequality, supra note 20 , at 1.

39. The "matric" year is the last year of high school, the equivalent of twelfth grade in the United States.

40. Diamond, supra note 9, at 901-02. Different commentators have arrived at slightly different numbers, but they paint the same general picture of inequality, See, e.g., Crouch, Dilemmas, supra note 32 , at 2 (stating that about one-quarter of African children enter life with a "matric pass," whereas usually two-thirds of whites do).

41. Education for All, supra note 37.

42. Id. Given that many black children's parents cannot read because of apartheid's discriminatory education policies, one could argue that schools play an even larger role in spreading literacy than they would in a society where more parents can themselves read and play a role in teaching their children. Under this line of reasoning, one could argue that the nation's poorest schools deserve not only equal but superior resources to make up for the disadvantages these children face. This has not happened, despite the Constitution's affirmative action provision. See S. Afr. Const. ch. 2, § 9(2) ("To promote the achievement of equality, legislative and other measures designed to protect or advance persons, or categories of persons, disadvantaged by unfair discrimination may be taken.").

43. Christine Liddell \& Gordon Rae, Predicting Early Grade Retention: A Longitudinal Investigation of Primary School Progress in a Sample of Rural South African Children, 71 Brit. J. Educ. Psychol. 413, 418 (2001). The authors define "disruption" as some difficulty that prevents children from proceeding naturally from one grade to the next. Indications of disruptions include leaving school, switching schools, or repeating grades. See id. at 422 .

44. A Fillip for South Africa's Schools, Economist, Jan. 6, 2001, at 43, 43 [hereinafter Fillip]. 
For instance, between 1994 and 1999, the number of twelfth graders taking the advanced mathematics required for university engineering programs dropped from 88,000 to $69,000 .{ }^{45}$ Far from effecting positive reforms, the Department of Education made things far worse, pensioning off thousands of the country's best teachers and administrators and letting academic standards slide. ${ }^{46}$

Moreover, recent curriculum reform has brought mixed results, stalling improvement even more. In 2000, the government decided to abandon its "Curriculum 2005" after determining that it was "too complex for most teachers" and neglected reading, writing, and arithmetic. ${ }^{47}$ The Outcomes-Based Education (OBE) that now underpins South African curricular reform, while earning better marks than Curriculum 2005, has proven to work best in "well-resourced" schools. ${ }^{48}$ That the chosen path of curricular reform works best in the schools that need the least help demonstrates not only that the inequity persists but that government measures to reform the system have so far failed to address the most serious problems. ${ }^{49}$ To be fair, since arriving on the job in June 1999, Mr. Asmal has received praise for his efforts, and the number of students passing their end-of-high-school exams has increased over the past year. ${ }^{50}$ However, even these strides are misleading; the increased pass rate is partially due to new restrictions on the number of pupils retaking papers they failed the previous year. ${ }^{51}$

A final obstacle to improving the quality of education is the culture of violence and sexual abuse that has become common in South African public schools. A recent study by Human Rights Watch says that sexual abuse by both teachers and other students is widespread in South African

45. Don Boroughs, New Opportunities for South Africa, ASEE Prism, May-June 1999, at $18,21$.

46. Fillip, supra note 44 , at 43 ; see also supra note 21 and accompanying text.

47. Karen MacGregor, Baffling Curriculum Dropped, Times (London), June 23, 2000, Educ. Supp., at 14.

48. David Macfarlane, Research: OBE Works Best in Resourced Schools, Mail \& Guardian (S. Afr.), Feb. 23-Mar. 1, 2001, at 26.

49. The federal government in South Africa determines most school funding, unlike in the United States where education funding is a predominantly state and local issue. While sections 229 and 230 of the Constitution do grant municipalities considerable taxation and borrowing powers, these powers are still subject to national legislation and regulation. Sections $139(1)(\mathrm{a})$ and (b) and $155(7)$ give the national and provincial governments executive and legislative authority to oversee the municipalities' performance of their functions. S. Afr. Const. ch. 6 (Provinces), $\S 139$, ch. 7 (Local Government), $\S 155$, ch. 13 (Finance), $\$ \$ 229-230$.

50. Fillip, supra note 44 , at 43 . As this Note was going to print, the Department of Education issued a lengthy report indicating greater recognition of the problem than this Part might indicate. It remains to he seen, however, whether this administrative attention will translate into actual reform without judicial intervention. See Report to Minister, supra note 19.

51. Fillip, supra note 44 , at 43 . 
schools. ${ }^{52}$ The phenomenon is most frequent in the poorest, mostly black neighborhoods, where some teachers take advantage of poor students by swapping small gifts for sex. ${ }^{53}$ In addition to highlighting what dangerous places South African schools have become, this trend is also having a pronounced negative impact on girls' education. In the worst neighborhoods, girls are coming to school less frequently and finding it harder to concentrate when they do. ${ }^{54}$ The government thus has to worry not just about facilities and teaching, but school safety as well. If administrators continue to turn a blind eye to their teachers' crimes, ${ }^{55}$ it will be increasingly difficult for the government to provide education for young black women, who, finding themselves already "at the bottom of a steep hierarchy of race, class and gender," are facing what one commentator has called an educational "emergency." 56

\section{The Constitutional Right to Education}

The quality of education in South Africa, particularly in many predominantly black areas, is poor, but to decide whether it is in fact unconstitutional, the contours of the right to education must be understood. Section A of this Part introduces section 29 of the Constitution, which promises the right to education, and argues that though the Constitution does not articulate a specific standard of schooling, it in fact requires an "adequate" education consistent with notions of democracy and citizenship. ${ }^{57}$ By closely analyzing the language of the Constitution and other Court decisions implicating socioeconomic rights, section $\mathrm{B}$ applies this standard of education to the current situation and argues that the Constitutional Court, given the opportunity, should find that the government has failed to meet its section 29 obligations for the poorest schools. ${ }^{58}$ In doing so, however, it must not usurp the other government

52. Human Rights Watch, Scared at School: Sexual Violence Against Girls in South African Schools 5 (2001).

53. 1d. at 44 .

54. 1d. at 61-64.

55. Id. at 74-76.

56. Ali A. Abdi, Economic Liberalization and Women's Education: Prospects for PostApartheid South Africa, 33 McGill J. Educ. 71, 83 (1998).

57. Part 1I.A looks at the text of the South African Constitution to argue that it requires the government to provide an adequate education. Part III defines this notion of adequacy more thoroughly, drawing on broader conceptions of education's role in a democracy.

58. Some might argue that while improved education is a noble and important goal in contemporary South Africa, it is not the courts' place to effect such changes. However, bureaucratic inertia and government corruption in South Africa conspire to make standard legislative reforms ineffective. South African courts, then, play a particularly crucial role in defining and protecting fundamental rights. See, e.g., Gov't of Rep. of S. Afr. v. Grootboom, 2001 (1) SA 46 (CC) (defining and protecting right to adequate housing). As indicated in note 50, the March 3, 2003 Department of Education Report demonstrates administrative effort to which the Court should be sensitive, especially at first. See Report to Minister, supra note 19. However, administrative gestures should not 
branches' roles. Section C explores the tensions between South Africa's aspirational Constitution and its limited resources and argues that the Court must uphold constitutionally protected socioeconomic rights, even if it is unclear whether the government can fully realize them yet. Indeed, improved education will ultimately help the government realize other constitutional objectives.

\section{A. The Constitutional Standard of Education}

The South African Constitution explicitly guarantees the right to education. Section 29 of the Constitution's Bill of Rights ${ }^{59}$ states that "Everyone has the right (a) to a basic education ... and (b) to further education, which the state, through reasonable measures, must make progressively available and accessible." 60 The Constitution clearly promises some level of education; that level, though, is not so easy to discern.

The White Paper on Education ${ }^{61}$ defines "basic" education as "compulsory" schooling-pre-school through ninth grade-and "further" edu-

deter judicial intervention if schools continue to remain poor, provided, of course, that the Court not intrude too much on the other branches.

The Constitutional Court has not yet ruled on the constitutionality of South African education. It has, however, decided other education cases, demonstrating that it is not afraid of hearing cases involving complicated policy issues that some might argue are best left for the legislature or Department of Education. See, e.g., Bel Porto School Governing Body v. Premier of W. Cape Province, 2002 (3) SA 265 (CC) (upholding school retrenchment program despite detrimental effect on some schools); Minister of Educ. v. Harris, 2001 (4) SA 1297 (CC) (holding that Minister of Education exceeded powers conferred upon him by section 3(4) of National Policy Act); In re Nat'l Educ. Policy Bill 83, 1996 (3) SA 289 (CC) (holding that bill did not impose obligation on provinces to conform to national educational policy but that if it did, provinces would be obliged to follow national policy); In re Gauteng School Educ. Bill of 1995, 1996 (3) SA 165 (CC) (holding that Constitution imposes no positive obligation on the state to establish public schools based on common language, culture, or religion); see also the Transvaal Provincial Division of the Supreme Court's decision in Matukane v. Laerskool Potgietersrus, 1996 (3) SA 223 (TPD) (determining that since plaintiffs had established prima facie case of racial discrimination, burden of proof shifted to school to disprove discrimination and that because school did not meet that burden, denial of admission to school contravened mandate of nondiscrimination in education).

59. The second chapter of South Africa's Constitution is the Bill of Rights, consisting of sections 7 through 39 of the Constitution. References to section 29 of the Constitution and section 29 of the Bill of Rights thus refer to the same provision.

60. S. Afr. Const. ch. 2 (Bill of Rights), $\$ 29(1)$.

61. The White Paper is a document written by the Department of Education, describing "the first steps in policy formation by the Ministry of Education in the Government of National Unity." White Paper, supra note 29, at ch. 1, para. 1. While they obviously lack the force of a constitution, "White Papers" on various policy issues are persuasive and have been consulted by judges and scholars alike to understand issues of socioeconomic rights. See, e.g., Crootboom, 2001 (1) SA at para. 47 (discussing the White Paper on Housing in its discussion of section 26's right to housing); Matthew Chaskalson et al., Constitutional Law of South Africa 38-9 (5th ed. 1999) (discussing White Paper on Education in connection with constitutional right to education). 
cation as "post-compulsory" education-tenth grade and beyond. ${ }^{62}$ Under the Constitution, basic education is a "strong positive right," a right that can be asserted regardless of the state's other budgetary imperatives. ${ }^{63}$ Unlike further education, which the government need only make "progressively available" "through reasonable measures," 64 the right to basic education appears absolute. While the government may decide how to structure its schools, section 29(1) (a) gives constitutional support to an unhappy parent who might demand that the state immediately provide her child with better education through the ninth grade..$^{65}$ By way of contrast, section 29(1) (b) provides not an absolute right to further education, but a right to reasonable governmental measures that make it progressively available. ${ }^{66}$ Thus, a student in tenth grade or higher may be able to show that her school fails to meet the constitutional standard, but in order to obtain a judicial remedy she also will need to show that the state has not made further education progressively available.

Though the Constitution provides for both basic and further education, section 29 does not make clear the quality of education the state must provide, so we must turn to other constitutional provisions for guidance. ${ }^{67}$ Does section 29 promise merely a place to go to school, or does it provide for an "adequate" education?

Unlike some American state constitutions, which provide for a specific quality of education, ${ }^{68}$ section 29 includes no such standard. A nar-

62. See White Paper, supra note 29, at ch. 5, paras. 14, 60 (discussing levels of education). The White Paper discusses grade levels using both American and South African terminology, because it intended for South Africa to switch to the American format. The South African equivalent to ninth grade is "standard seven." The cut-off between basic and further education remains a matter of controversy, see, e.g., Wildeman, supra note 33 , at 28 , but for constitutional purposes the key point is the mere fact of the distinction. This Note will refer to grade levels using the American terminology.

63. Chaskalson et al,, supra note 61 , at 38-1.

64. S. Afr. Const. ch. 2 (Bill of Rights), $\$ 29(1)$ (b).

65. See Chaskalson et al., supra note 61, at 38-1 (discussing the nature of strong positive rights).

66. S. Afr. Const. ch. 2 (Bill of Rights), § 29(1) (b); see also Chaskalson et al., supra note 61, at 38-1 (discussing further education as "weak positive right").

67. As this Part argues, both basic and further education need to be "adequate." Obviously, the curricular standards constituting "adequacy" will differ among age levels, but they ought to be determined by reference to the same principles of democracy. In other words, while further education is not an absolute right, when the government does provide it (and the government does need to make it progressively available), it needs to evaluate that further education with the same principles with which it evaluates basic education.

68. The New Jersey Constitution, for instance, requires the legislature to "provide for the maintenance and support of a thorough and efficient system of free public schools." N.J. Const. art. VIII, $\S 4$, I 1 (emphasis added). Other state constitutions require the establishment of "an adequate public education" or an "ample" education. Michael A. Rebell, Education Adequacy, Democracy and the Courts, in Achieving High Educational Standards for All 218, 232 (Christopher Edley et al. eds., 2002). See generally William E. Thro, The Role of Language of the State Education Clauses in School Finance Litigation, 79 Educ. L. Rep. 19 (1993) (summarizing education clauses in state constitutions). 
row reading of the text might then find that any education-whether adequate or not-satisfies the "basic" and "further" requirements, so long as it ostensibly addresses students in the relevant age or learning groups. Merely providing the opportunity to attend school would satisfy the state's constitutional obligations. However, the Constitution sets forth general provisions with which to interpret the Bill of Rights, and, relying on these, the Court should find that section 29 does in fact promise what some American state jurisprudence would call "adequate" education. ${ }^{69}$

The Bill of Rights itself opens with the insistence that the "state must respect, protect, promote and fulfil the rights in the Bill of Rights," 70 thus suggesting that the government must play an active role in continuing to improve access to positive rights. Additionally, section 39 of the Constitution requires courts interpreting the Bill of Rights to "promote the values that underlie an open and democratic society based on human dignity, equality and freedom." 71 1nterpreting section 29 to require the state merely to provide education, without any implicit quality standard, would thus pervert section 39's interpretative instructions. Not only would such an interpretation render section 29 virtually toothless, but also it would run counter to the democratic values the Constitution explicitly seeks to promote.

For a democracy to work, its populace must be educated enough to research and analyze its choices. Political philosophers such as Thomas Jefferson and John Dewey have long recognized the crucial role education plays in well-functioning democracies. ${ }^{72}$ Similarly, democratic societies protect their citizens' freedoms, so that people can pursue their goals and pecuniary well-being. In poorer, developing nations, however, negative liberty might not be enough to secure each individual's opportunity to compete in the marketplace; the government, in those instances, might need to take additional steps to give people the chance to participate in the first place. 1ndeed, economist Amartya Sen has argued that "[d] evelopment can be seen ... as a process of expanding the real freedoms that people enjoy." 73 To be sure, many democracies fall short of this ideal, but the ideal nonetheless remains fundamental to democratic theory. To argue, then, that section 29 promises a place to go to school, but not an adequate education, would undermine section 39's requirement that the Bill of Rights be interpreted to foster the values of a free and democratic society. ${ }^{74}$

69. The Bill of Rights, section 39 in particular, lays out the values with which one can determine exactly what quality of education is required. This Note uses the word "adequate" to embody the sum of those values, but it emphasizes that the content of that "adequacy" must be ascertained by reference to the South African Constitution itself.

70. S. Afr. Const. ch. 2 (Bill of Rights), $\$ 7(2)$.

71. Id. $\$ 39(1)$ (a).

72. See infra Part III.

73. Amartya Sen, Development as Freedom 3 (1999).

74. The primary treatise on South African constitutional law, written by leading South African legal scholars, reasons similarly, noting that public education's role is 1) "as a 
Adequate education is, indeed, essential to the realization of dignity, equality, and freedom. ${ }^{75}$ These section 39 values will not be realized universally in a single generation, but education offers the opportunity for some to succeed despite the oppressive chains of the past. Without such opportunity, South Africa's recently won civil and political freedoms seem hollow. One great tragedy of contemporary South Africa is that despite the replacement of a repressive, racist regime with a progressive, enlightened one, many people's lives have changed little on a day-to-day basis. Education is a vehicle for promoting equality and helping people attain not merely political but also socioeconomic freedom.

Moreover, section 39 states that courts "must consider international law" when interpreting the Bill of Rights. ${ }^{76}$ One treaty to which the Court has looked is the International Covenant on Economic, Social and Cultural Rights (ICESCR), which specifically recognizes "the right of everyone to education .... [ [that is] directed to the full development of the human personality and the sense of its dignity, and ... [to] the respect for human rights and fundamental freedoms."77 Given that the covenant speaks directly to the question of education, the Court should again turn

developer of human potential"; 2) "as a foundation for good citizenship"; and 3) "as a provider of functional efficacy in the labour market." Chaskalson et al., supra note 61, at $38-2$.

75. S. Afr. Const. ch. 2 (Bill of Rights), $\$ 39(1)$ (a).

76. 1d. $\$ 39(1)$ (b) (emphasis added). South Africa's constitutional commitment to human rights ideals is no accident. Much of international human rights law was formulated in the very period South Africa was erecting its apartheid state, so South Africa's human rights abuses profoundly shaped the course of that whole body of law. For instance, the international struggle against apartheid resulted in numerous United Nations General Assembly resolutions. Following emancipation, the liberators, themselves the beneficiaries of the international community's disdain for the apartheid state, quickly embraced international human rights. Professor Slye writes, "In what is certainly one of the most abrupt shifts in international reputation, South Africa moved from one of the most morally suspect nations in modern history to the poster child of the international human rights movement." Ronald C. Slye, International Law, Human Rights Beneficiaries, and South Africa: Some Thoughts on the Utility of International Human Rights Law, 2 Chi. J. Int'l L. 59, 61 (2001). The South African Constitution thus embodies the values of many modern, late twentieth century constitutions, espousing a commitment to what is generally called "constitutionalism." See, e.g., Louis Henkin, Constitutionalism, Democracy, and Foreign Affairs, 67 Ind. L.J. 879, 885-86 (1992) (discussing constitutionalism as the "commanding ideology of our time"); Louis Henkin, Sibley Lecture March 1994: Human Rights and State "Sovereignty," 25 Ga. J. 1nt'1 \& Comp. L. 31, 31 (1994-1995) (suggesting that half-century of human rights has been both cause and result of spread of constitutionalism).

77. International Covenant on Economic, Social and Cultural Rights, Jan. 3, 1976, art. 13, 993 U.N.T.S. 3, 9 [hereinafter ICESCR]. For an example of the Court's reliance on the ICESCR, see Gov't of Rep. of S. Afr. 7. Grootboom, 2001 (1) SA 46 (CC), paras. 26-29, 45 (citing ICESCR's "significance in understanding the positive obligations created by the socio-economic rights in the Constitution"). 
to the ICESCR to find that the Constitution promises an adequate education to promote democratic principles. ${ }^{78}$

Section 28 offers a final argument for requiring an adequate education. It considers children's rights generally and asserts, "A child's best interests are of paramount importance in every matter concerning the child." W9 While the Constitution does treat education separately (partially to cover adult education), this clause would seem to further strengthen a child's right to an adequate education. A plaintiff could thus argue that failing schools violate not only section 29 (as interpreted with reference to section 39 values) but also section 28 .

\section{B. The Constitutionality of Contemporary South African Education}

Having considered the state of current South African education and ascertained that the Court should read the Constitution to require an adequate education, we must now determine whether the state of education in South Africa today passes constitutional muster. To do so, we must first explore other decisions implicating socioeconomic rights and then consider the right to adequate education in light of those decisions. Finally, we must look briefly at equality, for while the Court should focus its attention on issues of educational adequacy, the school system is so blatantly unequal that the Court might also reference section 9 equality provisions.

1. Socioeconomic Rights in South African Jurisprudence. - South Africa's Constitution is "the world's leading example of a transformative constitution"; the document is designed to "ensure that future governments do not fall prey to anything like the evils of the apartheid era," ${ }^{80}$ and yet South African courts have struggled to reconcile the document's noble goals with difficult economic realities. The Constitutional Court's decisions have thus needed to determine exactly what the government is constitutionally obligated to provide. Three decisions that well highlight the

78. South Africa signed the ICESCR on October 3, 1994, but has not yet ratified it. However, under both the Vienna Convention on the Law of Treaties and customary international law, signatories to treaties are bound to refrain from acts that would defeat a treaty's object and purpose, even if they do not become parties. Vienna Convention on the Law of Treaties, Jan. 27, 1980, art. 18, 1155 U.N.T.S. 331, 336; see also Lori F. Damrosch et al., International Law: Cases and Materials 109 (4th ed. 2001) (noting that multilateral treaties can become customary international law binding on nonparties). Moreover, since South Africa's Constitution requires the Court to consider international law and since the Court has already referred to the ICESCR in interpreting socioeconomic rights, the Covenant is clearly relevant in interpreting South Africa's Bill of Rights.

79. S. Afr. Const. ch. 2 (Bill of Rights), $\$ 28(2)$. See generally J. Sloth-Nielsen, The Child's Right to Social Services, the Right to Social Security, and Primary Prevention of Child Abuse: Some Conclusions in the Aftermath of Grootboom, 17 S. Afr. J. Hum. Rts. 210 (2001) (exploring Grootboom's effect on socioeconomic rights for children).

80. Cass R. Sunstein, Social and Economic Rights? Lessons from South Africa 4 (Pub. Law \& Legal Theory, Working Paper No. 12, 2001), available at http://papers.ssrn.com/ paper.taf?abstract_id=296657 (on file with the Columbia Law Review) [hereinafter Sunstein, Lessons]. 
difficulty of this task are Soobramoney $v$. Minister of Health, ${ }^{81}$ Government of Republic of South Africa v. Grootboom, ${ }^{82}$ and Minister of Health v. Treatment Action Campaign $(T A C) .{ }^{83}$

Soobramoney is the Court's first socioeconomic rights case struggling to balance rights and resources. Plaintiff-appellant in Soobramoney was a diabetic suffering from kidney failure who sought to prolong his life through regular dialysis at a state hospital in Durban. The hospital, however, had only twenty dialysis machines, some of which were in poor condition, and had been unable to provide the appellant with the requested treatment. $^{84}$ Claiming that his constitutional rights had been violated, Soobramoney sued, relying on constitutional provisions stipulating that, "No one may be refused emergency medical treatment." 85 Justice Arthur Chaskalson emphasized the significance of this right, writing that a commitment to address the inequalities and injustices left over from apartheid and "to transform our society into one in which there will be human dignity, freedom and equality, lies at the heart of our new constitutional order." 86

However, the Court was also highly aware that limited resources and great economic disparities make it virtually impossible for the government to provide to its citizens everything that the Constitution promises, and Chaskalson admitted that "the Department of Health in KwaZuluNatal does not have sufficient funds to cover the cost of the services which are being provided to the public." 87 Indeed, he cited another section of the Bill of Rights that requires the state to "take reasonable legislative and other measures, within its available resources, to achieve the progressive realisation" of health care rights. ${ }^{88}$ Since the hospital's resources were severely limited, it needed to make decisions about how to use its twenty dialysis machines. The Court concluded that the hospital could benefit more patients if it continued its present course, providing treatment to patients who might be cured rather than simply maintaining the sickest in a chronically ill condition. ${ }^{89}$ Since the hospital was already well over budget, the Court argued that if it were to provide dialysis-and, by analogy, all life-saving treatment-to all patients in need, "the health

81. 1998 (1) SA 765 (CC).

82. 2001 (1) SA 46 (CC).

83. 2002 (5) SA 721 (CC).

84. Soobramoney, 1998 (1) SA at para. 1.

85. S. Afr. Const. ch. 2 (Bill of Rights), § 27(3). Mr. Soobramoney also invoked the provision stating, "Everyone has the right to life." $1 \mathrm{~d}$. $\$ 11$. The Court's opinion, however, focused on the medical treatment issue.

86. Soobramoney, 1998 (1) SA at para. 8.

87. 1d. at para. 24.

88. S. Afr. Const. ch. 2 (Bill of Rights), $§ 27(2)$ (emphasis added).

89. Soobramoney, 1998 (1) SA at para. 25. Argued the Court, "If everyone in the same condition as the appellant were to be admitted the carefully tailored programme would collapse and no one would benefit from that." Id. at para. 26. 
budget would have to be dramatically increased to the prejudice of other needs which the State has to meet." 90

The Court thus implied not only that South Africa simply lacked the resources to provide comprehensive, life-saving health care to all its citizens, but also that the judiciary ought not usurp the legislative function by implicitly assigning more funds to one important need at the expense of others. ${ }^{91}$ To find for Mr. Soobramoney, the Court would have needed to intervene immediately in the hospital's day-to-day operations, determining what constituted "emergency medical care" as opposed to ongoing treatment. In other words, the Court would not only have needed to order a particular government agency to do more, but it would have instructed that agency on exactly what to do, thus creating a separation-ofpowers problem that the Court sought to avoid. ${ }^{92}$

Significantly, even though the Court went to great lengths to justify the policy choice underlying its ruling, it also decided that Mr. Soobramoney's claim did not in fact fall under the Constitution. ${ }^{93}$ In finding that the care sought was ongoing dialysis, the Court concluded that it did not constitute "emergency medical treatment" and therefore did not qualify as a constitutionally protected right. ${ }^{94}$ The judges were clearly deeply affected by the moral implications of their decision and explained carefully that the state simply did not have the funds to provide the plaintiff with continual dialysis treatment. ${ }^{95}$ But however uncomfortable the Court was denying a dying man the medical services that could prolong his life, it was not obliged to order a state hospital to do more, because there had been no constitutional violation. ${ }^{96}$

The Constitutional Court confronted a similar issue in Grootboom: Exactly what government measures were required to satisfy the "progres-

90. Id. at para. 28.

91. The Court wrote, "The State has to manage its limited resources in order to address all these claims. There will be times when this requires it to adopt an holistic approach to the larger needs of society rather than to focus on the specific needs of particular individuals within society." Id. at para. 31.

92. See id. at para. 29 ("A court will be slow to interfere with rational decisions taken in good faith by the political organs and medical authorities whose responsibility it is to deal with sucb matters.").

93. Mr. Soobramoney did not even invoke section $27(2)$ which reads, "The state must take reasonable legislative and other measures, within its available resources, to achieve the progressive realisation of [health care] rights." S. Afr. Const. ch. 2 (Bill of Rights), § 27(2). The state, in fact, was working towards improving its health care system, and, in any event, Mr. Soobramoney's medical condition was too dire for "progressive realization" to do him any good.

94. Soobramoney, 1998 (1) SA at paras. 21, 36.

95. Justice Chaskalson noted with regret " $[t]$ he hard and unpalatable fact is that if the appellant were a wealthy man he would be able to procure such treatment from private sources." Id. at para. 31 .

96. This point is sometimes obscured by the Court's lengthy dictum about the difficulty of realizing socioeconomic rights witb limited resources. Such a discussion perbaps suggests that the right not to be refused emergency medical treatment could be expanded to include ongoing treatment were resources more readily available. 
sive realization" of the constitutionally protected right to housing? Having been evicted from their shanties erected on private land earmarked for formal low-cost housing, Mrs. Grootboom and other plaintiffs applied for an order requiring the government to provide them with adequate basic shelter until they obtained permanent accommodations. The lower court partially granted the order, requiring the government to provide all the plaintiffs who were children and their parents with shelter. The government appealed to the Constitutional Court.

Section 26 of the Constitution promises the right to adequate housing. ${ }^{97}$ The Court accepted that " $[\mathrm{t}]$ he State is obliged to take positive action to meet the needs of those living in extreme conditions of poverty, homelessness or intolerable housing"; the question was whether the state had met its obligations. ${ }^{98}$ Relying on section $26(2)$, which requires the state to take "reasonable legislative and other measures," 99 the Court found that the government had not done enough to provide adequate housing to the plaintiffs. Writing for the Court, Justice Yacoob asserted, "Mere legislation is not enough. . . . An otherwise reasonable program that is not implemented reasonably will not constitute compliance with the State's obligations." 100

Reasonable measures, therefore, cannot ignore "vulnerable groups," the people who most need the Constitution's protection:

The poor are particularly vulnerable and their needs require special attention. . . . Those whose needs are the most urgent and whose ability to enjoy all rights therefore is most in peril, must not be ignored by the measures aimed at achieving realisation of the right. ... If the measures, though statistically successful, fail to respond to the needs of those most desperate, they may not pass the test. ${ }^{101}$

The state, despite its limited resources, needed to do more:

$[\mathrm{T}]$ he fact that [the Constitution requires] realisation over time, or in other words progressively ... should not be misinterpreted as depriving the obligation of all meaningful content. 1t is on the one hand a necessary flexibility device, reflecting the realities of the real world and the difficulties involved for any country in ensuring full realization of economic, social and cultural rights. On the other hand, the phrase must be read in the light

97. Section 26's full text reads:

(1) Everyone has the right to have access to adequate housing.

(2) The state must take reasonable legislative and other measures, within its available resources, to achieve the progressive realisation of this rigbt.

(3) No one may be evicted from their home, or have their home demolished, without an order of court made after considering all the relevant circumstances. No legislation may permit arbitrary evictions.

S. Afr. Const. ch. 2 (Bill of Rights), $\S 26$.

98. Gov't of Rep. of S. Afr. v. Grootboom, 2001 (1) SA 46 (CC), para. 24.

99. S. Afr. Const. ch. 2 (Bill of Rights), $\$ 26(2)$ (emphasis added).

100. Grootboom, 2001 (1) SA at para. 42.

101. Id. at paras. $36,44$. 
of the overall objective ... which is to establish clear obligations for State parties in respect of the full realisation of the rights in question. It thus imposes an obligation to move as expeditiously and effectively as possible towards that goal. ${ }^{102}$

"Progressive realisation" of the right, then, means that the state must take steps to provide adequate housing, which "must be made more accessible not only to a larger number of people but to a wider range of people as time progresses." 103

Interestingly, the Court chose not to determine the minimum "core content" of the constitutional right to housing, focusing instead on whether the government's program was "reasonable," in light of the poor's particular vulnerability. ${ }^{104}$ In doing so, the Court emphasized the government's failed efforts to provide the right to the vulnerable, thus setting for the other governmental branches a high standard it ultimately found they had failed to meet. It found that section 26 obliges "the State to devise and implement a coherent, co-ordinated program designed" to provide adequate housing, and that the existing program had fallen short

102. Id. at para. 45 (internal citation omitted).

103. Id.

104. See id. at paras. $33,41,36$. Some scholars have argued that the Grootboom Court ought to have articulated the minimum core content of the right to housing. See, e.g, David Bilchitz, Note, Giving Socio-Economic Rights Teeth: The Minimum Core and 1 ts Importance, $119 \mathrm{~S}$. Afr. L.J. 484, 484 (2002) (arguing that "[ $\mathrm{t}]$ he judgment errs in its failure to interpret the right of access to adequate housing as including the idea of a minimum core obligation to provide lor basic needs"). It is not easy, however, for courts to articulate minimum core obligations. First, courts often lack the information needed to make such determinations. Second, different people need different levels of protection for a particular socioeconomic right to be meaningful for them. Third, it is unclear if the minimum core should be defined generally or with regard to specific groups (and, if the latter, then one could question whether a minimum core in fact exists at all, or is, instead, mere semantics). Id. at $486-87$.

In addition to the practical difficulties of articulating minimum core rights, one might query just how different such an approach would be from Justice Yacoob's "reasonableness" and "vulnerable groups" analysis; indeed, both seem particularly concerned with poor people, since, under a mininum core content analysis, the government will need to provide the indigent with the most to alleviate their need and meet their core obligations. See id. at 494-99. These approaches are, to be sure, different doctrinal hooks, but it is unclear how much, if anything, would be gained by requiring the Court to articulate a right's minimum core content, particularly given the Court's willingness to define rights by referring to section 39's interpretive instructions. If there is a significant difference between the two approaches, it could be that the minimum core content analysis might require judicial intervention even when vulnerable groups' rights are not at issue. From this perspective, the judiciary might want to steer clear of a minimum core content so that its ruling does not intrude too much on the legislature's prerogative. See Sandra Liebenberg, Socio-Economic Rights Project, Community Law Centre, UWC, South Africa's Evolving Jurisprudence on Socio-Economic Rights 38 (2002), available at http://www.communitylawcentre.org.za/ser/docs_2002/evolving_ jurisprudence.pdf (on file with the Columbia Law Review) (suggesting that advocates of pro-poor policies ... articulate a vision of socio-economic rights which goes beyond government granting relief to those in desperate need, but requires the needs of the poor to be prioritised in formulating policies and distributing resources."). 
of its obligations. ${ }^{105}$ Consequently, the Court issued a declaratory order requiring the state to act to meet its section 26 obligations by devising, funding, implementing, and supervising measures to provide housing relief to those in desperate need. ${ }^{106}$ The Court thus offered a novel approach to socioeconomic rights, requiring not that the legislature provide shelter for everyone, but rather that it adhere to sensible priorities with particular attention to the plight of the neediest. ${ }^{107}$

Significantly, Grootboom's holding encroaches less on the legislature than a pro-plaintiff decision in Soobramoney would have. In fact, it emphasizes that the different "spheres of government" must work "in consultation with each other" to devise a coordinated state housing program. ${ }^{108}$ Thus, whereas $\mathrm{Mr}$. Soobramoney would have had the Court determine for the hospital what constituted emergency care and order it to provide such treatment immediately, ${ }^{109}$ the Grootboom Court is merely telling the government that it must revise its policy to better address housing for the poor. Indeed, the Court found that the lower court had erred in ordering the government to provide the plaintiffs shelter or housing immediately because section 26 does not provide for such immediate action. Because the Grootboom Court permitted the state to formulate its plan-and gave it the time to do so-it avoided the separation-of-powers difficulty that providing a remedy in Soobramoney would have created.

Another important difference between the two cases is that, unlike Soobramoney, Grootboom found that the Constitution had in fact been offended: It holds that the government has breached its constitutional obligations for failing to protect a socioeconomic right. While this point is straightforward, it is, compared to American jurisprudence, remarkable. Government inaction-or, perhaps more correctly, ineffective and inadequate government action-can itself violate the Constitution, even though scarce resources might militate against requiring the government to do more. Wrote Justice Yacoob:

I am conscious that it is an extremely difficult task for the State to meet these obligations in the conditions that prevail in our country. . . I stress however, that despite all these qualifications, these are rights, and the Constitution obliges the State to give effect to them. This is an obligation that Courts can, and in appropriate circumstances, must enforce. ${ }^{110}$

105. Grootboom, 2001 (1) SA at para. 95. The Court rejected an argument emphasizing children's rights, choosing instead to focus more broadly on the reasonableness of the state's provision of the socioeconomic rights.

106. Id. at para. 96 .

107. Cass R. Sunstein, Designing Democracy: What Constitutions Do 229 (2001) [hereinafter Sunstein, Designing Democracy].

108. Grootboom, 2001 (1) SA at para. 40.

109. Mr. Soobramoney's condition required immediate care. A sad footnote to the case is that he died two days after the Court's decision. Justice Albie Sachs, Social and Economic Rights: Can They Be Made Justiciable?, 53 SMU L. Rev. 1381, 1386 (2000).

110. Grootboom, 2001 (1) SA at para. 94. 
Grootboom thus espouses a vigorous commitment to the judicial vindication of socioeconomic rights, and it is that path the Court recently followed in Minister of Health v. Treatment Action Campaign (TAC). ${ }^{111}$ The governmental program at issue provided voluntary HIV counseling and testing to pregnant women, and Nevirapine ${ }^{112}$ and formula feed for HIVpositive mothers. ${ }^{113}$ The question in this case, the first to challenge a policy designed exclusively by the ANC regime, was whether it was reasonable for the government to confine the administration of Nevirapine to research and training sites located in an urban and rural community in each province, as opposed to in hospitals throughout the nation. ${ }^{114}$ The Court, relying on Grootboom, insisted that the state had a "negative obligation" to desist from impairing the right of access to health care services and that confining the use of Nevirapine to certain hospitals breached the government's section 27 obligations. ${ }^{115}$ Emphasizing the state's constitutional obligations to provide citizens with certain socioeconomic rights, ${ }^{116}$ it held that the government must make every effort to include in the program everybody for whom the treatment could combat motherto-child transmission of HIV. ${ }^{117}$

Significantly, the Court once again articulated both "vulnerable groups" and "separation-of-powers" concerns. Like Grootboom, TAC insists that the State must take account of differences between "those who can afford to pay for services and those who cannot." 118 Thus, in dealing with the hard questions presented by the case, the Court reminded itself that "this case concerns particularly those who cannot afford to pay for medical services. To the extent that government limits the supply of Nevirapine to its research sites, it is the poor outside the catchment areas of these sites who will suffer." 119

111. 2002 (5) SA 721 (CC).

112. Nevirapine significantly limits the risk of an H1V-positive mother transmitting the disease to her fetus or breastfeeding child.

113. TAC, 2002 (5) SA at para. 41. Because Nevirapine was provided for free, the costs in question were the costs of providing the infrastructure for counseling and testing, and of providing formula feed and drugs to mothers and children receiving Nevirapine. ld. at para. 49 .

114. 1d. at para. 17 .

115. 1d. at paras. 46,80 . The relevant portions of section 27 state:

(1) Everyone has the right to have access to -

(a) health care services, including reproductive health care;

(b) sufficient food and water....

(2) The state must take reasonable legislative and other measures, within its available resources, to achieve the progressive realisation of each of these rights.

S. Afr. Const. ch. 2 (Bill of Rights), $\S 27$.

116. TAC, 2002 (5) SA at para. 94.

117. Id. at paras. 95,125 .

118. 1d. at para. 70 .

119. 1d. 
The Court also emphasized that its intrusion into policy-making must not tread too much on the other governmental branches. Courts, it noted, are ill-suited to make wide-ranging factual inquiries to determine minimum core standards. ${ }^{120}$ However, the Court-insisted that the government nonetheless was obliged to take necessary steps to "respect, protect, promote and fulfil" positive rights ${ }^{121}$ and "to take reasonable measures progressively to eliminate or reduce the large areas of severe deprivation that afflict our society." 122 The Court therefore ruled that the government had to do more to provide Nevirapine to all in need but allowed the government to craft the program itself. In permitting the government to devise a new program within its available resources, ${ }^{123}$ the TAC Court followed Grootboom in vindicating socioeconomic rights for the socially vulnerable, while at the same time remaining respectful of the other branches' duties. Our question now is the implications of these cases for the right to education.

2. The Government's Obligation to Provide Better Education. - An education case would fall under Grootboom and TAC, not Soobramoney, because the Constitution is clearly implicated, because a remedy exists that does not offend separation-of-powers principles, and because the protected right specially affects vulnerable groups. Whereas Mr. Soobramoney sought care beyond what the Constitution promised, plaintiffs in Grootboom and TAC were successful because the government had not provided reasonable plans to provide their constitutionally protected socioeconomic rights. Education, like access to housing and health care, is a positive socioeconomic right that the state must fulfill, ${ }^{124}$ so a failure to provide it would therefore clearly implicate the Constitution.

Furthermore, just as the Court could instruct the state to do more to provide housing or HIV treatment for the poor while still affording the legislature some time and flexibility to determine how, so too could it order the government to improve schools without itself legislating such changes immediately. To vindicate education plaintiffs' rights, the Court need not effect any overnight policy changes of the kind requested in Soobramoney. The Court can thus continue its strategy of protecting socioeconomic rights for the poor without unacceptably usurping the other branches' managerial role. ${ }^{25}$

120. Id. at paras. 37-38. See also supra note 104 .

121. Id. at para. 39 (quoting S. Afr. Const. ch. 2 (Bill of Rights), $\S 7(2)$ ).

122. Id. at para. 36 .

123. Id. at para. 135. Note that whereas Mr. Soobramoney was litigating his right to receive emergency medical treatment, the plaintiffs in TAC sued for their right to health care services, which the government must achieve progressively. The two decisions are therefore not incompatible, since the former finds that the treatment sought was in fact not emergency, while the latter determines that the government does need to do more to make health care services more available.

124. See id. at para. 100 (insisting that state has positive obligation to protect socioeconomic rights).

125. See Sunstein, Designing Democracy, supra note 107, at 222. 
Finally, just as Grootboom and TAC emphasized the fact that the plaintiffs were members of vulnerable groups whose interests were of particular governmental concern, so too could an education case seek to improve the country's worst schools. Interestingly, even though $\mathrm{Mr}$. Soobramoney was certainly "vulnerable" as an indigent diabetic, one can argue that such a case should not trigger vulnerable groups analysis, because he was seeking a specific remedy for only himself, as opposed to a broader plan to address a socioeconomic right denied to many "vulnerable" people. In this way, an education-rights case also would resemble Grootboom and TAC more than Soobramoney. Therefore, given South African education inadequacies, the Constitutional Court should draw on Grootboom and TAC to argue that current educational conditions in the worst schools violate the Constitution and that the government is obliged to do more to provide vulnerable groups with a better education. While South Africa may not have the resources to implement a school system equivalent to the world's wealthiest nations, the Court can still emphasize that current education in the poorest South African schools does not provide a foundation for ongoing personal development, civic activity, and employment. ${ }^{126}$

The government's best counterargument is probably not that the worst schools pass muster, but rather that under the section 36 Limitations Clause the government need not allocate resources it does not have. ${ }^{127}$ Here the Limitations Clause might allow the government to justify a limitation on education spending that under section 29 would be prima facie unconstitutional, if that limitation served a pressing public interest. ${ }^{128}$ ln other words, though section 29 (a) treats basic education as a strong positive right, the government might not have an absolute obligation to provide it, if it can point to a compelling government reason not to do so, such as severe budget problems. ${ }^{129}$

126. See Chaskalson et al., supra note 61 , at 38-3 (suggesting that courts judge basic education by reference to these civic norms); see also infra Part 11 .

127. Section 36 reads:

(1) The rights in the Bill of Rights may be limited only in terms of law of general application to the extent that the limitation is reasonable and justifiable in an open and democratic society based on human dignity, equality and freedom, taking into account all relevant factors, including-

(a) the nature of the right;

(b) the importance of the purpose of the limitation;

(c) the nature and extent of the limitation;

(d) the relation between the limitation and its purpose; and

(e) less restrictive means to achieve the purpose.

(2) Except as provided in subsection (1) or in any other provision of the Constitution, no law may limit any right entrenched in the Bill of Rights.

S. Afr. Const. ch. 2 (Bill of Rights), $\$ 36$.

128. Chaskalson et al., supra note 61 , at 12-47.

129. Id. at 38-1. 
Significantly, in Grootboom the Constitutional Court made no reference to section 36 limitations. ${ }^{130}$ While Grootboom's failure to mention section 36 does not, of course, render that clause irrelevant, it suggests that limitations are not at the center of constitutional interpretation of socioeconomic rights. The Court certainly must consider the government's budgetary constraints when determining whether its programs are constitutional, but, to the extent Grootboom provides guidance, if the "nature of the right" 131 is important enough to a democratic society based on freedom and equality, it will probably outweigh most limitations on that right. ${ }^{132}$ Thus, if the right is deemed crucial, it will tighten the limitation requirements that follow. ${ }^{133}$

That Grootboom implicitly considers housing to be such a crucial right-so crucial in fact that the Court did not even engage in a limitations analysis-suggests that basic education would also be one. The Constitution creates basic education as a strong positive right without reference to governmental resources. Housing, by way of contrast, is a weak positive right that requires the government to take "reasonable" measures "within its available resources, to achieve the progressive realisation of this right."134 Since the Court did not feel compelled to undergo a limitations inquiry for a weak positive right in Grootboom, it follows that it would also not limit the right to basic education, a strong positive right, even if the costs incurred were high. ${ }^{135}$

130. See Gov't of Rep. of S. Afr. v. Grootboom, 2001 (1) SA 46 (CC).

131. S. Afr. Const. ch. 2 (Bill of Rights), $\S 36(1)$ (a).

132. See, e.g., S v. Makwanyane, 1995 (3) SA 391 (CC) (holding that applicant's right to life was so crucial that it outweighed any interest government had in the death penalty).

133. Chaskalson et al., supra note 61 , at 12-50. The Court is conducting a sort of balancing test here, indeed the only "real" balancing test undertaken in South African jurisprudence. 1d. at 12-51. But see id. at 12-56 (arguing that though it happens, balancing constitutional rights can be confusing and, at times, impossible). To the extent, though, that the limitations will shrink if the right is an important one, it may be useful to think of rights as "trumps" here (though, given the existence of the Limitations Clause, probably not as absolute trumps in Dworkin's sense). If the right is crucial enough, it will almost certainly "trump" the limitation. See generally Ronald Dworkin, Taking Rights Seriously (1978) (arguing that political theory must take rights more seriously than it does and that rights derive not merely from political decisions and social practices).

134. S. Afr. Const. ch. 2 (Bill of Rights), $\S 26(2)$.

135. See Chaskalson et al., supra note 61 , at 41-49 (arguing that fact that fulfillment of right will require substantial resources is not itself sufficient reason to limit rigbt, because, if so, this approach would defeat purpose of including socioeconomic rights in Bill of Rights).

Note that one possible explanation for Crootboom's failure to engage in a section 36 analysis is that, unlike section 29 , section 26 includes an internal limitation so that an external section 36 limitations analysis would be redundant. See id. at 41-48 (discussing application of limitations inquiry). However, even if this is the case, it would not make sense for the external section 36 limitations inquiry to be more rigorous than an internal limitations inquiry such as section 26. Clearly the framers chose to create some strong positive rights like education and some weak positive rights like housing. They created general section 36 limitations, because they realized that socioeconomic rights could not be provided immediately, absolutely, and completely, but they could not have intended for 
After disposing of the limitation analysis ${ }^{136}$ (or ignoring it, as it did in Grootboom), the Court will still need to determine whether the Constitution compels the government to do more to provide adequate basic and further education. Basic education presents the easier case. Section 29(1)(a) creates basic education as a strong positive right containing none of the limitations that apply to health care or housing. ${ }^{137}$ As a matter of grammatical and constitutional interpretation, section 29(1) strongly suggests that the government has an absolute duty to provide basic education. ${ }^{138}$ Whereas the state only has to make further education "progressively available and accessible" "through reasonable measures," no such clause limits the obligation to provide basic education. ${ }^{139}$ Given

it to place as strong a limitation as internal limitations clauses, because if they had, they would not have chosen to make some positive rights strong and others weak. Thus, even if a section 36 analysis applies here but not in Grootboom, the rigor of that limitations analysis must be lower than in that case. Since limitations proved not to be an obstacle in Grootboom, as a matter of logic, it should also not be one here since the state in both cases is depriving people of their constitutional socioeconomic rights.

136. The Court might also argue that recent budget cuts were unnecessary, that while fiscal discipline is an important state objective, it cannot be pursued without regard to the state's constitutional obligation to provide certain socioeconomic rights. Under this line of reasoning, the country's budget problems might not even trigger the Limitations Clause.

137. See supra notes $60-66,93,102-105$ and accompanying text.

138. Section 29(1) reads:

(1) Everyone has the right -

(a) to a basic education, including adult basic education; and

(b) to further education, which the state, through reasonable measures, must make progressively available and accessible.

S. Afr. Const. ch. 2 (Bill of Rights), $\$ 29(1)$.

139. A counterargument to this interpretation might be that the qualifying clause in section 29(1) (b) ("which the state, through reasonable measures, must make progressively available and accessible") modifies not only "further education" but also "basic education." Under such a reading, the state would not be required to provide basic education iınınediately, but rather demonstrate that it was taking active steps to provide it "progressively." It would then only be violating its constitutional duties if the Court found, as it did in Grootboom, that its programs were not doing enough to improve the situation.

Such a reading, however, is unpersuasive. The limiting clause is attached only to "further education," and is separated from "basic education" by both a semicolon and a conjunction ("and"). Grammatically, it seems a stretch to apply the clause to "basic education." Moreover, if we compare section 29 (education) to section 26 (housing), we see that section $26(2)$ explicitly states that the government "must take reasonable legislative and other measures, within its available resonrces, to achieve the progressive realisation of this right." S. Afr. Const. ch. 2 (Bill of Rights), \$ 26(2). In other words, while the right promised in section $26(1)$-the right to have access to adequate housingappears absolute if read independently, the Constitution explicitly attaches to it section 26(2), which stipulates that the governınent can only be expected to take "reasonable" measures "within its available resources" to achieve the "progressive" realization of the right. See supra note 97 for full text of section 26. That the Court in Groolboom held that the lower court had erred in ordering the government to provide immediate housing to the plaintiffs confirms this reading.

By way of contrast, section 29(1) (b)'s limitations contain no such explicit reference to section 29(1)(a); unlike section 26, there is no clear indication in section 29(1) that the state need only make basic education "progressively available" using "reasonable 
the Constitution's adequate education requirement and the poor conditions of many schools, the Court should therefore hold that the government needs to provide better basic education immediately, regardless of its other budgetary concerns. ${ }^{140}$

While further education is not as easy a case as basic education, it fits within Grootboom and TAC's analysis; further education is a right the Court can require be made progressively more available without interfering in day-to-day bureaucratic decisions. Grootboom's test to determine whether the government has fulfilled its positive obligations to provide and protect socioeconomic rights is whether the measures adopted are "reasonable" given the needs of those whose rights are "most in peril."141 Given the Court's reasoning in Grootboom and the similarity between the country's substandard housing and school conditions, the Court should determine that the state has not taken reasonable measures to provide further education. ${ }^{142}$ Indeed, section $29(1)(b)$ offers even more textual

measures." Had the framers intended the state only to make basic education "progressively available" "within its available resources," they surely would have phrased section 29 differently. They either could have included a whole separate subsection qualifying the entire right, as they did in section 26 , or they could have tinkered with their punctuation and grammar to link the qualifying clause in section $29(1)$ (b) to the right in section 29(1)(a). That they did neither strongly suggests their intention to make "basic education" an absolute right that government must provide immediately.

140. Given the absolute terms of section 29(1)(a), the findings detailed in Parts 1 and Il.A, and the definition of adequacy given in Part 1II, this conclusion comes easily. To the extent skeptics find this reasoning unsatisfactory, however, the arguments that the Court should require the government to do more to provide further education also apply to basic education. As Part I demonstrates, both basic (pre-school to ninth grade) and further (tenth grade and beyond) education are far from adequate. Since the bar for finding current conditions unconstitutional for further education is higher than for basic education, the constitutional arguments asserting that further education is inadequate serve as additional, but probably unnecessary, arguments that the country's basic education is unconstitutional.

141. Gov't of Rep. of S. Afr. v. Grootboom, 2001 (1) SA 46 (CC), at paras. 41, 44; see Sandra Liebenberg, The Right to Social Assistance: The lmplications of Grootboom for Policy Reform in South Africa, 17 S. Afr. J. Hum. Rts. 232, 241 (2001) (discussing Grootboom in context of social assistance); see also Pierre De Vos, Grootboom, the Right of Access to Housing and Substantive Equality as Contextual Fairness, $17 \mathrm{~S}$. Afr. J. Hum. Rts. 258, 268-76 (2001) (discussing Grootboom in context of substantive equality).

142. South African housing and education conditions seem comparable for the poorest segment of the population in that neither fulfill the obligations of section 39 of the Bill of Rights. Just as shanties or, indeed, no housing at all, fail to promote "human dignity," so too does a school system in which only twenty percent of blacks reach the last year of high school fail to promote "equality and freedom." See supra Part l for other examples of educational shortcomings. Of course, section 39's standards are necessarily subjective, but a system in which so many people's most hasic needs are neglected seems necessarily contrary to the "values that underlie an open and democratic society based on human dignity." S. Afr. Const. ch. 2 (Bill of Rights), $\$ 39(1)$ (a). Note that this approach asks, as Grootboom did, what quality of education is reasonable in light of the inequalities already facing South Africa's poor. To pass constitutional muster, then, education must conform with section 39's standards, which might fluctuate as the country changes. Unlike a minimum core content analysis, see supra note 104 and accompanying text, this 
support for further education than section 26 does for housing. Whereas section 26 requires the government to take "reasonable legislative and other measures, within its available resources" to "achieve the progressive realisation" of access to adequate housing, ${ }^{143}$ section $29(1)$ (b) offers fewer qualifications to the right to further education. Section 29 nowhere mentions "available resources," thus suggesting that the state must make further education progressively available, even if it lacks the resources to do so. ${ }^{144}$ This omission suggests that education-including further education-is among the very highest state priorities, to be realized even when resources are at their scarcest. ${ }^{145}$

3. Equal Protection. - While the Court should focus on the right to education in section 29,146 the current state of South African education also violates the Constitution's guarantees of equal protection. Section 9 of the Bill of Rights states that "[e]veryone is equal before the law and has the right to equal protection and benefit of the law"147 and that "[e]quality includes the full and equal enjoyment of all rights and freedoms. To promote the achievement of equality, legislative and other measures designed to protect or advance persons, or categories of persons, disadvantaged by unfair discrimination may be taken."148 Since "[n]ational legislation must be enacted to prevent or prohibit unfair dis-

adequacy analysis does not set in stone particular requirements, but rather allows the courts to determine what seems "reasonable" given the country's circumstances and, more importantly, gives the legislature the leeway to play a major role in fashioning a constitutionally acceptable remedy.

143. S. Afr. Const. ch. 2 (Bill of Rights), \$26(2).

144. Obviously, a state cannot spend resources it does not actually have. However, the Constitution's language suggests that the Court still ought to uphold the importance of the right and urge the government to do more. See infra Part II.C.

145. From a functionalist standpoint, this conclusion may well make sense since improved education will help the nation achieve its other goals. See infra Parts II.C \& IIl.

Some might argue that this kind of close textual interpretation ought to be accompanied by an originalist argument; after all, some (though not all) proponents of close textual readings of the American Constitution insist that their readings are also rooted in originalist understandings. However, unlike the U.S. Constitution, the South African Constitution contains clauses guiding constitutional interpretation. Section 39 requires courts to "promote the values that underlie an open and democratic society based on human dignity, equality and freedom" when interpreting the Bill of Rights. S. Afr. Const. ch. 2 (Bill of Rights), $\$ 39$ (1)(a). An interpreter of the South African Constitution, particularly the Bill of Rights, thus has the luxury of having the framers' intent built into the document itself.

146. Though this Note argues here that the Court should not ignore section 9 equality issues, it believes the analysis should focus on the adequacy, rather than the equality, of the education. Equal education does not necessarily mean adequate education. Predominantly black schools might be "equal" to predominantly white schools, but if neither of those schools offers decent educations, then the victory is a hollow one. The Court should refer to inequalities to highlight the worst schools' inadequacies, but it should remember that merely making white and black schools equal will not necessarily satisfy the standards of section 29 .

147. S. Afr. Const. ch. 2 (Bill of Rights), $\$ 9(1)$.

148. Id. $\$ 9(2)$. 
crimination," 149 the Court should recognize that the government's failure to take stronger steps to remedy educational inequities constitutes a violation of section 9 .

One advantage of this argument is that it is easier to prove inequality than inadequacy. Inadequacy is often subjective, relying on general standards. While the democratic principles set out in section 39 provide the foundation for a definition of adequacy, ${ }^{150}$ reasonable people could differ over the finer points of that definition. Inequality, by way of contrast, is easier to establish. ${ }^{151}$ That a predominantly black province has twice as high a pupil-to-teacher ratio as a predominantly white province is clear evidence of inequality. ${ }^{152}$ Similarly, the startling differences between facilities also highlight gross inequities. ${ }^{153}$ Indeed, some have argued that school fees themselves violate section 9 , because schools in wealthy districts that are able to collect higher tuition can spend far more money per learner. ${ }^{154}$

Moreover, an equal protection analysis well suits South Africa's contemporary concerns. Equality ranks high on the "rainbow nation's" list of goals; the Constitution itself instructs judges to interpret it to further equality. The Court's own "vulnerable groups" analysis in Grootboom and $T A C$, while not explicitly resting on equal protection grounds, certainly is sensitive to these values. Indeed, following this approach, one could argue that poor schools should in fact receive more resources to give them a chance to catch up to the wealthier ones. Because the inequity in South African schools today is not merely due to funding differences but to the lingering effects of apartheid's systemic biases, equality may be impossible without these more radical measures. ${ }^{155}$

149. 1d. $\$ 9(4)$.

150. See infra Part III.

151. Unlike U.S. federal constitutional law, for example, Washington v. Davis, 426 U.S. 229 (1976), the South African Constitution does not require plaintiffs to prove government intent to establish an equal protection violation. See S. Afr. Const. ch. 2 (Bill of Rights), $\S 9(4)$.

152. See supra notes $30-31$ and accompanying text.

153. See supra notes 33-36 and accompanying text; see also BeI Porto School Governing Body v. Premier of W. Cape Province, 2002 (3) SA 265 (CC) (finding that white disabled schools were not worse off than other disabled schools, and that redeployment scheme intended to benefit understaffed schools therefore did not unfairly discriminate against them).

154. See Roithmayr, Constitutionality of School Fees, supra note 19.

155. See supra notes 20-26 and accompanying text (explaining why black schools remain so inferior to white ones and suggesting that poorer schools can only catch up if they are given more money than richer ones). Of course, merely providing poorer schools with increased funding will not alone solve the problem; those schools also need to learn to manage those resources efficiently and to adopt strategies to teach disadvantaged students. See generally L. Crouch \& T. Mabogoane, When the Residuals Matter More than the Coefficients: An Educational Perspective, J. Stud. Econ. \& Econometrics, Aug. 1998, at 1; Luis Crouch \& Thabo Mabogoane, No Magic Bullets, Just Tracer Bullets: The Role of Learning Resources, Social Advantage, and Education Management in Improving the Performance of South African Schools 2 (Apr. 1998) (unpublished manuscript, on file 


\section{The Tension Between Aspirations and Realities}

Of course, it is easier to proclaim constitutional ideals than to realize them. Even were the Court to require that government do more to provide adequate education, there is no guarantee that the legislature would or could satisfy that requirement. Some might argue that to announce standards that cannot be met would ultimately cheapen the Constitution; the Court can preach whatever message it wants, but that message-and the Constitution itself-will ring hollow once people begin to realize that its rulings do not improve their everyday lives. A narrow constitution, goes the argument, is better than an empty one.

Neither the Court nor the Constitution itself is blind to these pressures. The Bill of Rights, as previously noted, contains a Limitations Clause that implies that socioeconomic rights at times must be limited due to budget shortcomings. ${ }^{156}$ Similarly, the Court has identified this difficulty both implicitly and explicitly. In Soobramoney, Justice Chaskalson, before ultimately denying the plaintiff relief, wrote:

We live in a society in which there are great disparities in wealth.

Millions of people are living in deplorable conditions and in great poverty. There is a high level of unemployment, inadequate social security, and many do not have access to clean water or to adequate health services. These conditions already existed when the Constitution was adopted and a commitment to address them, and to transform our society into one in which there will be human dignity, freedom and equality, lies at the heart of our new constitutional order. For as long as these conditions continue to exist that aspiration will have a hollow ring. ${ }^{157}$

The Grootboom Court, though arriving at a different holding, wrestles with the same issue. 1t opens with the admission that the case "grapples with the realisation of these aspirations" of human dignity, equality, and the advancement of human rights and freedoms. ${ }^{158}$ "The case," it writes, "brings home the harsh reality that the Constitution's promise of dignity and equality for all remains for many a distant dream." 159

with the Columbia Law Review) (attempting to assess impact that financial resources, management, and "contextual poverty" have on educational performance in South African schools).

Sen has argued that people's freedom grows out of their "capability," their ability to live comfortably and pursue their life goals. Sen, supra note 73, at 75. Poverty, of course, diminishes people's capabilities, id. at $87-110$, so that "the substantive freedoms that we respectively enjoy . . . are extremely contingent on personal, social, and environmental circumstances." ld. at 283-84. To the extent that improved education can help improve people's capabilities, more equal education could be an important vehicle to help many South Africans find the freedom they have lacked for so long.

156. See S. Afr. Const. ch. 2 (Bill of Rights), $\$ 36$ (considering limiting factors).

157. Soobramoney v. Minister of Health (KwaZulu-Natal), 1998 (1) SA 765 (CC), para. 8; see also supra Part II.B.l (discussing Soobramoney).

158. Gov't of Rep. of S. Afr. v. Grootboom, 2001 (1) SA 46 (CC), para. 1; see also supra Part Il.B.1 (discussing Grootboom).

159. Grootboom, 2001 (1) SA at para. 2. 
However, while the Court has identified this tension in both cases, it has yet to articulate a rigorous rationale for why the judiciary should protect socioeconomic rights even when resources are scarce. Soobramoney, Grootboom, and $T A C$ do not claim to be the Court's final or definitive statement on these matters. This should be no surprise; the problem is an intractable one, and no solution is wholly satisfactory. And yet, while the difficulties of economic conditions should in no way be minimized, there are important arguments for why the Court should insist upon the realization of an adequate education as a fundamental right, even if the government's capacity to deliver significantly improved schools is questionable.

For one, as the primary interpreter of the Constitution, the Court finds itself in the best position to reaffirm the country's commitment to equality and dignity for all. In a country where so many people lived under oppression for so long, popular constitutionalism is hard to come by. ${ }^{160}$ Socioeconomic improvements, to be sure, will be crucial to South Africa's future, but it is also important that people do not lose their commitment to the Constitution's ideals. While some black South Africans are economically better off now than they were in I994, for many others the absence of apartheid's oppression and the constitutional commitment to human dignity is the major difference in their lives.

These ideals are certainly not enough, and commentators would be foolish to believe that these improvements are themselves a completed victory. But if championing these rights without realizing them risks emptying the Constitution, then abandoning them altogether would surely drain out even more of its content. In fact, as one commentator notes, the risk has always existed that "the Constitutional Court would become the preserve of the wealthy," the place where the wealthy white, robbed of its monopoly of the legislature and bureaucracy, would "use its affluence to monopolise the law."161 To abandon the Bill of Rights' commitment to socioeconomic rights so early in South Africa's ambitious con-

160. This is not to say that citizens lack political consciousness. However, many people who once vigorously opposed apartheid are now less politically active, less attuned to the day-to-day workings of the government. Instead, they harbor a vague grudge that the government has forgotten them. See, e.g., Lester Venter, When Mandela Goes: The Coming of South Africa's Second Revolution 169-86 (1997) (discussing difficulty of reforming masses' political concerns).

161. Johnny Steinberg, Court Sparks Revolution or Does 1t?, Bus. Day (Johannesburg), Oct. 10, 2000, at 11, available at http://www.bday.co.za/bday/content/ direct/0,3523,717355-6078-0,00.html (on file with the Columbia Law Review); see also Shedrack C. Agbakwa, Reclaiming Humanity: Economic, Social, and Cultural Rights as the Cornerstone of African Human Rights, 5 Yale Hum. Rts. \& Dev. L.J. 177, 177 (2002) (contending that economic, social, and cultural rights are key to effectively realizing human rights in Africa). Others have suggested that the current Constitutional Court, many of whose members were themselves once human rights advocates, will prove to be the high watermark of rights-based jurisprudence. E.g., Steve Kahanovitz, Legal Director, Legal Resources Centre, The Changing Nature of Public Interest Law in South Africa, Remarks at Columbia Law School (Oct. 17, 2002). If the future does in fact bring more 
stitutional experiment would exacerbate that risk. It would also relieve the government of any obligation to provide for the destitute masses still suffering from apartheid's lingering effects. The Constitution, after all, not only establishes these rights but empowers the Court to "grant appropriate relief" 162 and to declare when the government has acted unconstitutionally. ${ }^{163}$ Stated bluntly, to insist upon the right to an adequate education risks making an empty pronouncement, but to refuse to do so guarantees that the Constitution will become a mere shell of itself.

Indeed, in addition to protecting educational rights, the Court can continue a novel and important process of redefining the judiciary's role in a democracy so that courts can insist upon defining crucial rights while still leaving implementation to the other branches. The South African Constitutional Court has begun to stake out new ground for itself, and further decisions on socioeconomic rights could go a long way towards preserving the progress it has made. Thus can the Court remain "respectful of democratic prerogatives and of the limited nature of public resources, while also requiring special deliberative attention to those whose minimal needs are not being met." ${ }^{164}$ Indeed, by following its Grootboom and TAC decisions, the Constitutional Court can continue a process that Cass Sunstein argues "for the first time in ... history" seeks to ensure the protection of human rights "without placing courts in an unacceptable managerial role." 165

It is also important to remember that government implementation of any Court order need not happen overnight. Even though section 29(1) suggests that a basic education needs to be made available immediately (as opposed to further education, which need only be made "progressively available and accessible"), ${ }^{166}$ difficult economic realities make immediate vast improvements unrealistic. Indeed, judicial precedent is sensitive to this problem; Grootboom reversed the lower court's holding that the government needed to provide plaintiffs with housing "immediately upon demand." 167 The Court's task is then to find that middle ground between creation of a fully enforceable right, on the one hand, and the conclusion of complete nonjusticiability, on the other. This is, admittedly, an unfamiliar approach in most constitutional law, but its requirement of "reasoned judgment, including reasonable priority-setting," 168 is precisely the sensible path, respectful of democratic preroga-

executive and commercially minded decisions, one could argue that building precedent protecting socioeconomic rights now is particularly important.

162. S. Afr. Const. ch. 2 (Bill of Rights), $\$ 38$.

163. S. Afr. Const. ch. 8 (Courts and Administration of Justice), $\$ 172(1)$.

164. Sunstein, Lessons, supra note 80 , at 1 .

165. Id.

166. See supra Part II.B.2.

167. Gov't of Rep. of S. Afr. v. Grootboom, 2001 (1) SA 46 (CC), para. 95.

168. Sunstein, Lessons, supra note 80 , at 12 . Sunstein argues that the South African Constitutional Court in Grootboom adopted an "administrative law model of socio-economic 
tives and of the limited nature of public resources, while also remaining attentive to the needs of society's most vulnerable. ${ }^{169}$

The Court must recognize that the government cannot make all necessary changes at once, but a decision reaffirming the significance of education in South Africa's Constitution nevertheless would likely prompt some change. Following Grootboom, the state began "the struggle to effectively implement the norms" articulated in the Court's decision. ${ }^{170}$ Local governments, in particular, were forced to recognize that they risked violating the Bill of Rights if they did not meet the short-term needs of the most disadvantaged. ${ }^{171}$ Because the Grootboom and TAC cases were so recent (October 2000 and July 2002), it is too early to know whether the government will be able to implement these decisions successfully. ${ }^{172}$ What is clear, though, is that both local and federal governments have taken steps to comply with the decisions. An education ruling could spark similar government action, catalyzing, one hopes, a process of gradual reforms and improved collaboration between different branches and levels of government. ${ }^{173}$ A Court decision could thus push the government branches to go further. Indeed, to the extent that government corruption and bureaucratic inertia-and not just limited resources-contribute to the problem, a judicial ruling can also put the government's shortcomings in the spotlight. ${ }^{174}$

rights . . call[ing] for ... some sort of reasonable plan, designed to ensure that relief will be forthcoming to a significant percentage of poor people." ld. at 13.

169. Sunstein, Designing Democracy, supra note 107, at 221-22.

170. UN Working Group on the Right to Development, Case Study: South Africa (Sept. 2000), at http://www.fiop.org/reports/rtd/safrica.html (on file with the Columbia Law Review).

171. From the Courts: Grootboom v. Oostenberg Municipality, Local Government Law Bulletin (Apr. 2001), at http://www.sn.apc.org/users/clc/localgovt/bulletin/ 01 (1)frc1b.htm (on file with the Columbia Law Review).

172. The Carr Center for Human Rights Policy at Harvard's John F. Kennedy School of Government has begun a study of the aftermath of Grootboom to uncover what the decision actually means to the community and government housing authorities. The results at this early stage, however, are inconclusive. See Carr Center for Human Rights Policy, Case Studies: Housing Rights in South Africa, at http://www.ksg.harvard.edu/ cchrp/c_studies.shtml (last modified Mar. 4, 2003) (on file with the Columbia Law Review) (discussing study). Obviously, TAC is far too recent for a study of its effects to be worthwhile.

173. American school reform, for instance, has brought some encouraging new forms of "collaboration between courts, legislatures, and administrative agencies ... and between these organs of government and new forms of public action. . . . It thus redefines the separation of powers, and recasts the administrative state more generally, while opening the way to new forms of citizen participation in the orientation and operation of key public institutions." James S. Liebman \& Charles F. Sabel, A Public Laboratory Dewey Barely Imagined: The Emerging Model of School Governance and Legal Reform 4 (Oct. 2002), available at http://www.law.Columbia.edu/sabel/papers.htm (on file with the Columbia Law Review).

174. In the realm of education, for instance, schools have proven to be negligent in collecting textbooks from students at the end the school year. As a result, the education system has been losing more than R300,000 a year, arguably enough to provide 100 new 
In addition to reaffirming its new role and encouraging legislative reform, a judicial opinion would also help galvanize public opinion. There is among the poor in South Africa a lingering malcontentedness, but not a strong sense of how to make the situation better. ${ }^{175}$ Grootboom and TAC's policy implications may not yet be known, but they thrust housing and AIDS issues into the forefront of the nation's consciousness. In a country where so many people are uneducated-and therefore arguably less attuned to the opportunities afforded by a good education-a decision calling attention to educational rights might well help people recognize that it is in their own interests to work towards improved schools. Significantly, these efforts could be directed at more than just government reform, though it is ultimately the legislature that must provide the infrastructure and resources to make schools work. Communities could stress education more vigorously; parents could center their children's lives more around their school obligations. Law, thus, can not only be shaped by public opinion but can itself influence changes in public attitude. ${ }^{176}$ By affirming the significance of the right to education, the Constitutional Court could spur government reform and a popular sentiment in favor of better schools.

schools every year. Independent Online, Textbook losses $=100$ new schools a year, Mar. 4 , 2003, at http://www.iol.co.za/ (on file with the Columbia Law Review). Courts might want to use such disheartening trends both to justify their own involvement and to call attention to the disparity between legislative norms and street-level implementation. The Grootboom court used this approach when it emphasized that it was the government's implementation of the legislative program that had been unreasonable. Gov't of Rep. of S. Afr. v. Grootboom, 2001 (1) SA 46 (CC), at para. 42. Thus can the Court emphasize that constitutionally adequate legislative policy does not necessarily translate into constitutionally adequate implementation. See also supra Part Il.B.1.

The significance of this power is not to be underestimated in a country where the media's credibility is frequently under fire. The press, to be sure, can be quite critical of the government, but government officials, in return, aggressively try to manipulate and discredit hostile media. See, e.g., Sechaba ka'Nkosi, ANC Meddles in News Reports, Mail \& Guardian (S. Afr.), Apr. 24-May 1, 1998, at 13 (describing government's various means of punishing journalists who publish negative stories). The Justices on the Constitutional Court, however, are more generally respected; a ruling from them is worth far more than dozens of newspaper editorials and is therefore the country's best chance of calling popular attention to ineffective bureaucracy.

175. See, e.g., Venter, supra note 160, at 167-201 (exploring poor people's attitudes in South Africa).

176. William Eskridge eloquently makes this point in the context of Vermont's same sex domestic partnership rights. See William N. Eskridge, Jr., Equality Practice: Liberal Reflections on the Jurisprudence of Civil Unions, 64 Alb. L. Rev. 853, 877 (2001) (arguing that "law cannot liberalize unless public opinion moves, but public attitudes can be influenced by changes in the law"). Obviously, there are far more differences than similarities between education rights in South Africa and gay rights in Vermont. Nevertheless, the basic point is that law, particularly when proffered by the inoral authority of judges, can shape public attitudes. See also Sunstein, Designing Democracy, supra note 107, at 235 (arguing that judicial guarantees of socioeconomic rights can direct "political attention to interests that would otherwise be disregarded in ordinary political life"). 
Moreover, the Court should keep in mind that a decision would not only affect South Africa today but likely would have ramifications for generations to come. It is important that the Court not sever links with the Constitution's ideological commitment to socioeconomic rights. Assuming that South Africa's economy will continue to grow, ${ }^{177}$ the country's ability to meet fully its constitutional obligations will improve. A decision refusing to realize a constitutionally protected right would serve as an unsettling precedent and might in fact strip the Bill of Rights-not just the Education Clause- of most of its content. Indeed, while a pro-education decision today could force the government to do more now, it also will require the state to make education progressively better as the country's resources improve. Alternatively, bowing to current financial pressures might freeze future courts' ability to defend education and, potentially, other socioeconomic rights. ${ }^{178}$ Allowing the Constitution's ideals to stagnate seems far less desirable than issuing a decision with which the state can only partially comply.

Finally, and perhaps most importantly, beyond the general arguments defending what skeptics might call an "aspirational" ruling, education serves as the foundation of much of what South Africa wants to accomplish. ${ }^{179}$ Because social problems tend to be interconnected, reformers ought to ask which issues underlie others and address those problems that might also benefit other areas. Under this theory, when resources are limited, the rights government should first protect are those that will help achieve other goals. ${ }^{180}$ In this way, reform does not

177. An interesting and troubling question is how the Court should handle these issues if the country's economic conditions worsen. To an extent, the Court could continue to assert the importance of the right, recognizing that the state's compliance will be limited by fiscal difficulties. Indeed, such a decision would not be inconsistent with Grootboom, which insists that the legislature do more, but leaves it up to that branch to decide exactly how to do it. However, such a decision could also emphasize the need for more effective government (i.e., less corruption) and more equal distribution of resources. In this way, the Court could continue to respect the Constitution's commitment to socioeconomic rights while remaining sensitive to current conditions (and potentially spurring a grassroots movement committed, say, to improved education or to reducing government corruption).

178. Interestingly, future South African courts are not the only judicial bodies that might be affected by this decision. South Africa's Constitution has received considerable attention worldwide, and its commitment to socioeconomic rights serves as an inspiration-and a basis for comparison-in other countries. See, e.g., Balakrishnan Rajagopal, The Supreme Court \& human rights, The Hindu (India), Dec. 6, 2000, available at http://www.hinduonnet.com/thehindu/2001/12/06/stories/05062524.htm (on file with the Columbia Law Review) (comparing Indian Supreme Court decision on human rights with Grootboom and citing Grootboom as emblematic of "contemporary global trends and standards").

179. See infra Part III.

180. Of course, one difficulty here is that many different social goals are interconnected. One could certainly argue, for instance, that people will have difficulty bettering their lot in life without the stability of adequate housing. Education, though, seems particularly foundational. See infra Part I1I. 
necessarily trade one good for another, but rather can tackle multiple problems simultaneously. ${ }^{181}$ Indeed, one school of thought even argues that the economy - the chief concern driving the reduced budget in education and other social services ${ }^{182}$ - would in fact grow more if resources today were turned towards "expansionary fiscal policy" that increased people's potential by providing them with the skills needed to compete in the workplace. ${ }^{183}$ Thus might many of South Africa's problems be more easily addressed if the populace were better educated and possessed the "capability" to help itself. ${ }^{184}$

The AIDS crisis presents an important, if unique, example of how improved education might address other social problems. Experts estimate that by 2011 , over half the South African population will live in households affected by at least one HIV/AIDS infection. ${ }^{185}$ The poverty implications, already apparent, could dramatically increase health care costs and decrease economic productivity due to ill or deceased workers or household members tending to ill family members. ${ }^{186}$ In short, AIDS in South Africa is a crisis.

Obviously, drug treatment is essential for those already infected, and a host of political, economic, and legal issues (particularly debates over intellectual property laws) surround that problem. However, educating people, particularly children and teenagers, about the dangers of AIDS and ways to guard against them, will also need to play a large role in Africa's desperate struggle against the disease. Sex and death are taboo topics in much of African society, so communities have been reluctant to begin dealing with the AIDS crisis. ${ }^{187}$ Because so many myths surround the disease, ${ }^{188}$ it is probably unsurprising that the number of infections have risen at an alarming rate over the past decade. Countering these

181. Because so many social problems are not isolated, institutions seeking social change are perhaps inost effective when tbey seek to address interrelated problems. See, e.g., Michael C. Dorf \& Charles F. Sabel, Drug Treatment Courts and Emergent Experimentalist Government, 53 Vand. L. Rev. 831, 873 (2000) (exploring how drug treatment and job training-policy issues outsicle the criminal justice system-can work with, not against, drug courts so that government does not need to trade off between employment policy and drug policy). See generally Michael C. Dorf \& Charles F. Sabel, A Constitution of Democratic Experimentalism, 98 Colum. L. Rev. 267 (1998) (proposing system of democratic experimentalism which permits citizens to use local knowledge to fit given circumstances, while encouraging national coordinating bodies to pool information resources and thereby increase efficiency, encourage mutual learning, and heighten accountability).

182. See supra Part 1 (discussing policy of fiscal discipline).

183. E.g., Nicolaou, supra note 16 , at 90 .

184. See supra note 155 (discussing how improved education can increase freedom as conceptualized by Sen).

185. Liebenberg, supra note 141 , at 235.

186. Id.; In Mandela's Shadow, Economist, Dec. 14, 2002, at 23, 23.

187. Southern Africa's Unmentionable Cure, Economist, July 5, 1997, at 47, 47.

188. Many Africans refuse to believe that sexual intercourse can spread a disease. Some believe, in fact, that infected men can cure themselves of the illness by having sex with a virgin. $1 \mathrm{~d}$. 
myths is no small task, but schools could potentially play a large role in doing so. ${ }^{189}$ In fact, encouraging schools to tackle a tangible problem like a nationwide health crisis might help convince the population that improved education is in fact something from which everyone will benefit. ${ }^{190}$ Admittedly, improved AIDS education would not necessarily improve education generally. However, the mere strategy of using schools to educate the population about an urgent matter might encourage the state to provide schools with more resources and might also help inculcate a commitment to education.

Improved education might also help address other problems. South Africa has one of the world's highest crime rates, ${ }^{191}$ in part because many see little opportunity for economic gain outside a life of crime. Education can help expand people's horizons and, hopefully, guide some potential criminals to real professions. Reduced crime rates could, in turn, help attract international investments, one of President Mbeki's strategies for improving the economy. ${ }^{192}$ A more educated, skilled workforce might also attract such investment. Education can thus address a host of national concerns, including the very economic issues that counsel against extending government resources to pay for better schools.

There are, of course, no easy fixes. Lackluster schools will not be turned around overnight, and even tangible improvements will not necessarily translate immediately into other social spheres. Indeed, while there is certainly reason to believe that improved schools can help South Africa attack AIDS, crime, and economic woes, it would be naive to assume that better schools would accomplish such objectives quickly. A more skilled workforce, for instance, will not, on its own, create better jobs. However,

189. This is particularly true in urban squatter camps, many of which lack any community meeting place other than schools. Rootless, most squatter camp residents come from afar and hope to settle there only temporarily. The result is that these places lack any sense of community, a phenomenon that makes educating the populace about the dangers of AIDS even more difficult.

In fact, one could argue that educating children and teenagers about AIDS prevention is not only a wise but a consututionally required measure. Section 27 of the Constitution requires the state to take "reasonable legislative and other measures" to provide access to health care. S. Afr. Const. ch. 2 (Bill of Rights), \$27(2). Not only could AIDS education in schools constitute preventive health care itself, but, if effective, it could help reduce the number of future AIDS cases, thus lightening the cost of nationwide health care. In this way, increased resources to education could in fact save the country vast amounts of money in the long run.

190. Of course, this could cut the other way, too. Communities skeptical that AIDS is transmitted through sex could conceivably become less enamored of school's role in society. However, while this is a short term risk, it is more likely that the realities about AIDS will ultimately take hold, and people will begin to recognize the importance of disseminating life-saving information.

191. E.g., Survey: The Endless Assault, Economist, Feb. 24, 2001, at 7, 7-8 [hereinafter Endless Assault].

192. Thabo Mbeki, Building the Economy (Mar. 26, 1996), reprinted in Africa: The Time Has Come: Selected Speeches of Thabo Mbeki 163, 165 (1998) [hereinafter Mbeki, Speeches]. 
nation building takes time, and the Court must realize that its decisions today will sow the seeds for what the country can accomplish tomorrow. It should not sacrifice the future benefits of better schools just because it is impossible to know exactly what those benefits will be.

While these arguments militate in favor of affirming the Constitution's aspirational values, the opposing viewpoint is not a frivolous one. There is a certain wisdom to the stance that the Court should not order the government to do what it simply cannot. And yet, while this tension should not be dismissed lightly, the ideals behind South Africa's Bill of Rights are too important-and too firmly planted in the actual text of the Constitution - to abandon, even if the logistics of implementation are difficult and unclear.

\section{Democratic Theories of Educational Adequacy}

\section{A. Political Theory and the Relevance of American Law}

This Note has argued that current South African basic and further education violate section 29 , and that the Court should draw on both the Constitution's text and its own precedent to hold that the government needs to do more to improve the country's worst schools. However, while the condition of South African schools and the relevant legal arguments provide a good case for this outcome, the inquiry should not end there. The argument that the worst schools fail to pass constitutional muster is premised on an understanding of educational "adequacy" that needs to be further explored. ${ }^{193}$

In addition to providing a theoretical underpinning for a constitutionally mandated standard of education, a definition of adequacy clarifies for the legislature the kind of education it must provide. Such a ruling, like Grootboom and TAC, defines the right for the state but ultimately allows the other branches to craft a remedy. It also helps the Court justify its action. From an instrumentalist perspective, the kind of open, democratic society envisioned by the new Constitution's framers demands adequate education. Without it, too many of society's social, political, and economic goals will be unattainable. Thus, in the effort to define an "adequate education," the Court can also articulate political and philosophical reasons why it must hold unconstitutional the nation's education system. In fact, invoking such reasoning might also help the Court justify to a potentially skeptical public why it has chosen to privilege education.

193. The principles of adequacy explored in this Part should apply to both basic and further education. While the Constitution establishes a more absolute right to basic education, schooling both before and after tenth grade plays a large role in nurturing a healthy democracy. Thus, while the government need only make further education "progressively" available, the further education that it is required to make available must conform to the notions of adequacy articulated here. In other words, while the government must provide basic education inumediately and further education gradually, both basic and further education must be "adequate" to meet the requirements of section 39. 
To the extent that resources in South Africa are limited, a Court decision ordering the state to do more to protect one right might come at the expense of others. If the Court finds itself in the unenviable position of "rationing" rights, it could also justify its decision by connecting its definition of "adequacy" to a philosophical discussion of education's crucial role in society, thereby suggesting that a good educational system can help the country attain other protected rights. Education is then not only a right but also a social foundation for other goals, a starting point for a host of necessary social changes. ${ }^{194}$ In this way, promoting education, while possibly constricting the state's ability to address other problems in the short term, may foster the kind of social, political, and economic growth that ultimately will allow the government to address many other problems more successfully.

As previously noted, section 39 instructs the Court on where to look for guidance in interpreting the Bill of Rights. Just as it proved helpful in determining that section 29 establishes a right not merely to education but to "adequate" education, so too can it help elucidate what "adequacy" entails. Section 39 requires the Court to "promote the values that underlie an open and democratic society based on human dignity, equality and freedom." 195 While this provision does not explicitly instruct the Court how to define "adequacy," it requires that the Court consult these values to ascertain more specifically what kind of education the Constitution mandates.

Section 39 also states that the court, in addition to examining international law, "may consider foreign law."196 American case law, particularly state decisions, is one place for the Court to search for theories linking education with democratic ideals. Over the past thirty years, American plaintiffs have turned to state constitutions to find a right to adequate education, ${ }^{197}$ providing a wide body of reasoning from which South Africa could draw. Many state constitution education clauses were written in the nineteenth century and reflect the democratic ideals of the common school movement, which created systems of public education

194. See supra notes $179-192$ and accompanying text.

195. S. Afr. Const. ch. 2 (Bill of Rights), $\$ 39(1)$ (a); see also Enver Motala \& John Pampallis, Educational Law and Policy in Post-Apartheid South Africa, in Motala \& Pampallis, supra note 15 , at 14,30 (arguing that the state must intervene in education policy so that education can help redress historical injustices, ensure a human rights culture, and permit all individuals to compete in the international econoiny).

196. S. Afr. Const. ch. 2 (Bill of Rights), $\$ 39$ (1)(c).

197. In 1973, the United States Supreme Court held in San Antonio Independent School District $v$. Rodriguez that education is not a fundamental right under the Constitution and that under the Equal Protection Clause of the Fourteenth Amendment, the poor are not a "suspect" classification entitled to special protections. 411 U.S. 1, 1-2 (1973). Consequently, the Texas school system in that case did not violate the Federal Constitution, and future education-rights plaintiffs have needed to bring their claims under state constitutional law. 
that attempted to foster democratic values. ${ }^{198}$ Thus does the tradition of these constitutions link education and democracy. Indeed, even as nineteenth century public officials tried to hammer out the details of the new state constitutions, they "talked about the importance of a virtuous, intelligent, independent, rational, competent populace to guide the arm of government." 199 Such a Jeffersonian model of society necessitates public schooling, ${ }^{200}$ and it is this "republican" vision of "public virtue"201 that provides the foundation for recent education-finance-reform litigation in many American states. ${ }^{202}$ Significantly, since 1989 education-rights plaintiffs have prevailed in eighteen of twenty-eight decisions in the state high courts, ${ }^{203}$ and the school districts in question appear to be improving. ${ }^{204}$ These decisions form a rich body of literature that the Constitutional Court might consult. ${ }^{205}$

Not only are the American cases rooted in the same democratic kinds of ideals that section 39 espouses, but they also reflect a society similar to South Africa in crucial ways. The Constitutional Court may be able to find other countries whose laws fit its own more closely-Germany and Canada, for instance, have constitutions and legal systems more akin

198. Rebell, supra note 68 , at 245 ; see also Thomas James, Rights of Conscience and State School Systems in Nineteenth Century America, in Toward a Usable Past: Liberty Under State Constitutions 117, 121-22 (Paul Finkelman \& Stephen E. Gottlieb eds., 1991) (discussing common schooling as one of great reform movements of nineteenth century); G. Alan Tarr, Understanding State Constitutions 131 (1998) (explaining that the new constitutions of southern states during Reconstruction expanded government support for education and other social programs).

199. Laura J. Scalia, America's Jeffersonian Experiment: Remaking State Constitutions 1820-1850, at 132 (1999).

200. See, e.g., Jefferson, supra note 1, at 148-49 (arguing that because the people themselves are government's only "safe depositories," public education must be required).

201. Brigham v. State, 692 A.2d 384, 392 (Vt. 1997).

202. In forty-four of the fifty American states, plaintiffs have launched constitutional challenges to state education finance systems. Rebell, supra note 68, at 218 .

203. ld. at 228 .

204. See Douglas S. Reed, On Equal Terms: The Constitutional Politics of Educational Opportunity 22-29 (2001) (providing statistical evidence to argue that education funding has become higher and more equal in states where school-financereform litigants won, suggesting that judicial remedies can in fact accomplish their intended effects both generally and in the context of school reform). Of course, skeptics might point out that many of these cases, such as the Abbott cases in New Jersey, have been returning to the courts for decades, demonstrating that the judiciary's efforts to resolve these issues have remained unsuccessful. See Gerald N. Rosenberg, The Hollow Hope: Can Courts Bring About Social Change? 42-71 (1991) (arguing that courts are poor midwives of social change and that judicial decisions such as Brown $v$. Board of Education effected little reform during subsequent civil rights movement until other branches intervened).

205. To be sure, the South African Court will be highly aware of differences between the two countries. American commentators would be tunnel-visioned if they thought that South Africa should look exclusively to American experiences, especially given American public schools' shortcomings. Nevertheless, the American courts' reasoning might still prove to be useful, and the different states' successes and failures could help elucidate the relative merits of various judicial approaches. 
to South Africa's ${ }^{206}$ - but America's historical experiences make it a suitable place for South Africa to look on this topic. ${ }^{207}$ South Africa and the United States share vast disparities in wealth that make equal and adequate school funding difficult to attain. ${ }^{208}$ Additionally, both South Africa and the United States can trace the inequities in their education systems back to state-sponsored racism: slavery, Jim Crow, and continued segregation in America; apartheid in South Africa. ${ }^{209}$ The remnants of this racist heritage are very visible in both countries' schools; inequalities in both school systems tend to break down along racial lines. ${ }^{210}$ Of course, the United States abandoned formal segregation decades ago, while South Africa held its first democratic elections only in 1994. It is for that very reason, though, that South Africa could learn from the past several decades of American jurisprudence.

206. See, e.g., Jeremy Sarkin, The Effect of Constitutional Borrowings on the Drafting of South Africa's Bill of Rights and Interpretation of Human Rights Provisions, $1 \mathrm{U}$. Pa. J. Const. L. 176, 184-87 (1998) (noting that provisions of South African Constitution have origins in Canadian and German law); see also Bruce Ackerman, The New Separation of Powers, 113 Harv. L. Rev. 634, 640 (2000) (noting that the South African and Canadian constitutions fit broad model of "constrained parliamentarianism"); Ruti Teitel, Transitional Jurisprudence: The Role of Law in Political Transformation, 106 Yale L.J. 2009, 2060 n.205 (1997) (discussing affinities between South Africa's and Germany's postwar constitutions).

207. See, e.g., Diamond, supra note 9, at 854, 861 (arguing that similarities in South African and American history merit a comparison of the two countries' rights to education). It is interesting to note that South Africans themselves sometimes point to America's racial problems to highlight the "mundane and systematic character of oppression" and to argue that in both South Africa and the United States, the lack of access to adequate education is due to "second generation discrimination." E.g., John Powell, Affirmative Action in Education: A Second Look, Mail \& Guardian (S. Afr.), Feb. 23-Mar. 1, 2001, at 26 (South African newspaper article drawing on American experience to argue for affirmative action in South African schools).

208. Most countries have disparities, but South Africa's and the United States's are particularly pronounced. Since local communities often fund public schools (directly in South Africa, through property taxes in the United States), these inequities translate directly into uneven schools. See Reed, supra note 204, at 94-95 (noting that while many Americans believe school funding ought to be equal, few Americans are actually willing to pay higher taxes or help fund non-local school districts); R. Craig Wood \& David C. Thompson, Educational Finance Law: Constitutional Challenge to State Aid Plans-An Analysis of Strategies 16 (1996) (explaining that while state taxes generate the base of school funding, local school boards generally are responsible for raising the rest of their revenue, so that wealthier districts which can generate higher property taxes are able to provide better schools); supra Part I (discussing why South African schools remain unequal).

This Note does not argue that increased funding alone is sufficient to provide an adequate education. However, because a quality education incurs so many expensesteacher salaries, school supplies, school facilities, etc.-this author does believe that substantial funding is necessary to provide adequate education.

209. See, e.g., A. Leon Higginbotham, Jr., Racism in American and South African Courts: Similarities and Differences, in The Unpredictable Constitution 26, 27-29 (Norman Dorsen ed., 2002) (comparing and contrasting American and South African racism).

210. Diamond, supra note 9 , at 912 . 
A South African court can, of course, consider multiple aspects of the American decisions, such as their remedies. ${ }^{211}$ 1t can also explore the increased interaction in America between different branches of government, as courts and legislatures struggle to decide exactly what kind of education is required and how best to provide it. ${ }^{212}$ It is the political philosophies underlying those decisions, though, that will be especially helpful to a South African court seeking to define the scope of the constitutional right and to balance social aspirations against fiscal realities. Indeed, theories that see education as central to the political process, socialization, and economic opportunity speak not just broadly to education's general importance but more specifically to the difficulties facing South Africa today.

\section{B. Education and the Political Process}

Education is vital for a society that relies on democratic elections to choose its government officials and decide important public policy issues. ${ }^{213}$ Almost a century and a half ago, Alexis de Tocqueville recognized that in democratic societies like the United States, "the instruction of the people powerfully contributes to the support of the democratic

211. See, e.g., Leandro v. State, 488 S.E.2d 249, 255 (N.C. 1997) (requiring sound education to provide sufficient ability to read, write, and speak English; sufficient fundamental knowledge of geography, history, and basic economic and political systems; sufficient academic and vocational skills to engage in postsecondary education or vocational training; and sufficient academic and vocational skills to enable students to compete on an equal basis with others); Tenn. Small Sch. Sys. v. McWherter, 851 S.W.2d 139, 150-51 (Tenn. 1993) (citing Tennessee Constitution, which requires state education to provide "opportunity to acquire general knowledge, develop powers of reasoning and judgment, and generally prepare students intellectually for a mature life"); Campaign for Fiscal Equity v. State, 719 N.Y.S.2d 475, 483-87 (N.Y. Sup. Ct. 2001), rev'd 744 N.Y.S.2d 130 (N.Y. App. Div. 2002) (noting that to achieve "foundational skills that students need to become productive citizens capable of civic engagement and sustaining competitive employment," school systems need sufficient numbers of qualified teachers and administrators, appropriate class sizes, adequate and accessible school buildings, sufficient and up-to-date books and supplies, suitable curricula, adequate resources for students with extraordinary needs, and a safe, orderly environment); see also Abbott v. Burke III, 643 A.2d 575, 576 (N.J. 1994) (court retaining right to intervene if needs of poorer districts are not met). Note that even though the New York Appellate Division reversed the New York Supreme Court's 2001 CFE decision, the case is being appealed to the New York Court of Appeals, and, at any rate, the South African judiciary is free to borrow from any foreign decision, regardless of whether it actually carried the day. Chaskalson et al., supra note 61, at $41-16-41-19$.

212. See generally Liebman \& Sabel, supra note 173 , at 4 ("The core substantive commitment of the emergent system is the provision to all students, and particularly to racial and other minorities, whom the public schools have traditionally short-changed, of an adequate education, where the definition of adequacy is continuously revised in the light of the improving performance of the best schools.").

213. Section 39 explicitly refers to these concerns, requiring courts to promote values underlying "an open and democratic society." S. Afr. Const. ch. 2 (Bill of Rights), $\$ 39(1)$ (a). 
republic."214 Indeed, many would argue that democratic citizenship comes with responsibility, and that citizens need the skills to deliberate carefully. ${ }^{215}$ Thus does South Africa, which held its first democratic elections in 1994, have an interest in an educated populace capable of making thoughtful decisions and contributing to an open, democratic society. In fact, some critics believe that South Africa's greatest political weakness is its lack of a viable opposition party. Because it was the party of Nelson Mandela and liberation, the ANC is indisputably the dominant political party in South Africa today, so much so that some feel it has become, at best, less dynamic and, at worst, corrupt. ${ }^{216}$ To the extent this might be true, education could play a key role in sharpening the populace's critical thinking skills so that they hold the government more accountable for its shortcomings. The Court should make explicit the connection between education and democracy, both to define "adequacy" and to justify its decision. Doing so might help the Court make clear that it does not intend to usurp the legislative function, because the Court would be explaining a potentially counter-majoritarian ${ }^{217}$ decision in democratic terms.

American state cases provide examples of such justifications. In a New York case, for instance, the court asserted that students needed a basic education that would allow them to "function productively as civic participants capable of voting and serving on a jury." 218 A California court noted that "education prepares students for active involvement in political affairs. ... [It] stimulates an interest in the political process and provides the intellectual and practical tools necessary for political action. Indeed, education may well be the dominant factor in influencing political participation and awareness." 219

Even the United States Supreme Court, which does not recognize a national right to education, has reasoned similarly. Most famously, the Court in Brown v. Board of Education unanimously asserted "the importance of education to our democratic society. It is required in the per-

214. Alexis de Tocqueville, Democracy in America 329 (Henry Reeve trans., Vintage Books 1945) (1839).

215. E.g., Richard Arneson \& Ian Shapiro, Democratic Autonomy and Religious Freedom: A Critique of Wisconsin v. Yoder, in Democracy's Place 137, 147-48 (Ian Shapiro ed., 1996) [hereinafter Shapiro, Democracy's Place].

216. See, e.g., Courtney Jung \& Ian Shapiro, South Africa's Negotiated Transition: Democracy, Opposition, and the New Constitutional Order, in Shapiro, Democracy's Place, supra note 215, at 184-87 (arguing that effective opposition to ANC government is "virtually impossible"); see also Interview by Terry Gross with Archbishop Desmond Tutu (Fresh Air, National Public Radio Broadcast, Nov. 2, 1999) (discussing negative ramifications of lack of viable opposition party in South Africa).

217. See Alexander Bickel, The Least Dangerous Branch: The Supreme Court at the Bar of Politics 16-17 (1962).

218. Campaign for Fiscal Equity, Inc. v. State, 655 N.E.2d 661, 666 (N.Y. 1995).

219. Hartzell v. Connell, 679 P.2d 35, 40-41 (Cal. 1984) (internal quotation marks omitted). 
formance of our most basic public responsibilities . . ."220 Remarkably, even in San Antonio Independent School District v. Rodriguez, which refused to recognize a federal right to education, the majority acknowledged that democracy "depends on an informed electorate: a voter cannot cast his ballot intelligently unless his reading skills and thought processes have been adequately developed."221

It is significant that this argument appeals even to the United States Supreme Court. While many, including the four dissenting justices, believe that Rodriguez was wrongly decided-that the Supreme Court ought to have struck down the Texas school funding program-the case is certainly close enough that reasonable people can differ over the wisdom of its holding; the outcome might seem unjust, but the majority is correct that, even though education is vital to a healthy democracy, the United States Constitution does not explicitly provide for it. ${ }^{222}$ By way of contrast, the South African Constitution does. If the connection between education and democracy made sense to a United States Supreme Court reluctant to acknowledge socioeconomic rights, then surely it is appropriate for a South African Constitutional Court whose Constitution explicitly instructs it to do so.

\section{Education and Socialization}

Any definition of educational adequacy also must recognize that education serves a crucial function of binding people together in democratic societies. Education theorist John Dewey saw one of its chief functions as socializing youth into a democratic culture, ${ }^{223}$ and, while education's goals are hardly limited to this, school frequently offers children their first connections with their peers. Thus, for Dewey, curricular details were less important than the larger question of how education enables the child to become a full member of society. ${ }^{224}$

This theory of education seems especially relevant to South Africa, a country struggling to reconcile itself with the horrors of its past. Instilling

220. Brown v. Bd. of Educ., 347 U.S. 483, 493 (1954). Though San Antonio 1ndependent School District v. Rodriguez, 411 U.S. 1, 29-39 (1973), closes the door on the possibility of a federal right to education, Brown is still of tremendous symbolic importance in education rights, particularly for a country like South Africa struggling with some of the same racial issues America was struggling with then. 1ts dictum on education may not be good American federal law, but it is the kind of philosophical statement that would be especially noteworthy for South African courts examining foreign law. See Chaskalson et al., supra note 61, at 41-19 (discussing Rodriguez to suggest that South African courts can learn more from its affirmation of education's importance than from its ultimate holding).

221. Rodriguez, 411 U.S. at 36.

222. But see Missouri v. Jenkins, 495 U.S. 33, 55-58 (1990) (determining that federal court could require school district to impose taxes in excess of state statutory limits to fund school desegregation plan). Jenkins certainly does not overrule Rodriguez, but it suggests that Rodriguez might not be the death knell of federal constitutional educational rights.

223. Alan Ryan, John Dewey and the High Tide of American Liberalism 175 (1995). 224. 1d. at $182-83$. 
a sense of community and civic virtue is a step towards a national understanding similar to that sought by the country's Truth and Reconciliation Commission. ${ }^{225}$ For a country whose constitution values "human dignity" and whose society struggles to come to terms with a brutal past and a violent present, ${ }^{226}$ education serves an especially crucial state function of trying to instill in its citizens a sense of respect for other human beings.

Several American education decisions reflect a similar vision of education's role in society. Brown asserted that education "is the very foundation of good citizenship." 227 More recently, the California Supreme Court, in asserting free public education's central role in democratic society, noted "education serves as a unifying social force among our varied population, promoting cohesion based upon democratic values." 228 Another California judge, drawing on similar principles, quoted Dewey's argument that " $[\mathrm{t}]$ he only way to prepare for social life is to engage in social life."229

Similarly, education serves an important function in a liberal, plural society. ${ }^{230}$ To serve a country well, education needs to bring together children from different backgrounds. ${ }^{231}$ This ideal conforms closely to South Africa's vision of itself as a "rainbow" nation"232 "committed to the building of a democratic, non-racial, and non-sexist" country. ${ }^{233}$ of course, since South African society remains so segregated, it will be difficult to integrate the school system completely, but the country must make an effort because, as Dewey recognized, schools are the key social institutions in building an integrated, multicultural society. ${ }^{234}$

225. See generally Desmond Mpilo Tutu, No Future Without Forgiveness (1999) [hereinafter Tutu, Forgiveness] (arguing that TRC was essential step towards achieving national reconciliation); Paul van Zyl, Dilemmas of Transitional Justice: The Case of South Africa's Truth and Reconciliation Commission, 52 J. 1nt'l Aff. 647, 663 (1999) (exploring paradoxes in truth commission model but concluding that " $[t]$ ruth has a democratizing effect because it is more difficult to sustain arbitrary and repressive rule in a society comprised of citizens who know the terrible costs of human rights abuse").

226. See, e.g., Endless Assault, supra note 191, at 7 (exploring why South Africa has become "one of the most violent countries in the world").

227. Brown v. Bd. of Educ., 347 U.S. 483, 493 (1954).

228. Hartzell v. Connell, 679 P.2d 35, 41 (Cal. 1984) (internal quotations omitted).

229. Smith v. Regents of Univ. of Cal., 844 P.2d 500, 526 (Cal. 1993) (Arabian, J., dissenting) (internal quotation marks omitted).

230. See Ryan, supra note 223, at 364 (noting Dewey's defenses of multicultural education as integral to liberal, plural society).

231. Id.

232. See, e.g., Tutu, Forgiveness, supra note 225 , at 87 (discussing the moral victory that all South Africans-the "rainbow people of God"-experienced upon defeat of apartheid).

233. Thabo Mbeki, We Have Come Home: Remarks at Opening Session of the Organisation of African Unity Conference of Ministers of Information (Oct. 4, 1995), reprinted in Mbeki, Speeches, supra note 192, at 195, 196.

234. Ryan, supra note 223, at 364; see also Liebman \& Sabel, supra note 173 , at 135-36 (concluding that standards-based reform movement in United States provides encouraging method of dealing with racial issues in aftermath of desegregation). 
The Constitutional Court can again turn to American decisions to find these principles. In Sheff $v$. ONeill, in which the Connecticut Supreme Court required that the education guaranteed in the state constitution be consistent with the contemporary meaning of "an adequate education," a concurring judge discussed the significance of scholastic racial diversity to our broader democratic society:

Children of every race and ethnic background suffer when an educational system is administered on a segregated basis . . . . [I] $\mathbf{n}$ our multicultural world, [education] includes the development of social understanding and racial tolerance. If the mission of education is to prepare our children to survive and succeed in today's world, then they must be taught how to live together as one people. Anything less will surely result in a segregated society with one racial and ethnic community pitted against another. ${ }^{235}$

Nowhere should this vision of education fostering interracial unity be more applicable than South Africa. Theories of socialization and multiculturalism might not be enough on their own to provide an independent theoretical foundation for a rigorous definition of "adequacy," but given their relevance to South Africa's ongoing transition and the virtues espoused by some of the country's leading public intellectuals, such as Archbishop Desmond Tutu, ${ }^{236}$ they certainly merit mention.

\section{Education and Economic Opportunity}

Section 39's promotion of dignity, equality, and freedom also implicates economic rights. When it determined that long-term equality required a commitment to a free market economy, the ANC government abandoned its revolutionary Marxist leanings and committed itself to capitalism. ${ }^{237}$ In recent years, it has further strengthened that commitment, opting to reduce the deficit at the expense of social programs; fiscal discipline, the government decided, would be the engine for future economic growth. ${ }^{238}$ For that new economy to achieve the government's goals, though, people must be given the skills to fuel that development. Without solid schooling, many people will lack the chance to do so, and

235. Sheff v. O'Neill, 678 A.2d 1267, 1294 (Conn. 1996) (Berdon, J., concurring).

236. See, e.g., Tutu, Forgiveness, supra note 225, at 7-8 (discussing first democratic elections' transformative effects on whites and blacks and arguing that "South Africans will survive and prevail only together, black and white").

237. See, e.g., Sparks, supra note 6, at 366-67 (discussing weakening of South African Communist Party and rift between ANC and Communist ideologues upon liberation); see also Thabo Mbeki, Transforming the Economy of South Africa: Remarks at the South African Chamber of Business Annual Banquet (Sept. 14, 1995), reprinted in Mbeki, Speeches, supra note 192, at 96,97 (stating that "as government we have the responsibility to ... evolve policies which will produce conditions of stability and engender confidence in private investors that we are able to manage the economy in a responsible manner").

238. See, e.g., Oldfield, supra note 15, at 44-45; Nicolaou, supra note 16, at 89. 
growth will be constrained by a population consisting of only a small percentage of educated elites capable of handling sophisticated jobs.

American courts have also recognized education's centrality in a well-functioning capitalist society. Brown noted that education was a principal instrument "in preparing [students] for later professional training" and continued that "it is doubtful that any child may reasonably be expected to succeed in life if he is denied the opportunity of an education." 239 Another court bluntly asserted that without the right to education, "neither the student nor the state has a future."240

A recent New York decision was more specific:

Today's economy demands that all high school graduates, whether they are continuing their education or are moving directly into the workforce, have higher levels of skills and knowledge. ...

[T] he minimum skills necessary to compete successfully for good jobs are high-level academic skills. Opportunities for lesseducated workers are likely to keep declining, while continued increases in the service sector will bring more good jobs to people with computer skills who are literate, can write, and are wellgrounded in science and mathematics. ${ }^{241}$

South Africa's economy and job market are, to be sure, different from New York's, but as it strives to be an economic leader in sub-Saharan Africa, South Africa too will have increasing numbers of jobs requiring high-level academic skills. And, of course, not only will the country want people to be able to fill those jobs, but only those individuals possessing such skills will have a real chance to compete in the marketplace. Quite simply, as the California Supreme Court put it, education "prepares individuals to participate in the institutional structures . . . that distribute economic opportunities and exercise economic power. Education holds out a bright hope for the poor and oppressed to participate fully in the economic life of . . . society." 242

Under this theory, then, education is less about "encouraging the very cleverest to climb the highest intellectual peaks," and more about "making children competent members of society." 243 As Jefferson argued, one of education's main functions is to allow people to develop

239. Brown v. Bd. of Educ., 347 U.S. 483,493 (1954).

240. Fla. Dep't of Educ. v. Glasser, 622 So. 2d 944, 948 (Fla. 1993).

241. Campaign for Fiscal Equity v. State, 719 N.Y.S.2d 475, 487 (N.Y. Sup. Ct. 2001) (quoting the 1996 National Education Summit) (internal quotation marks omitted). But see Campaign for Fiscal Equity, Inc. v. State, 744 N.Y.S.2d 130, 134 (N.Y. App. Div. 2002) (reversing DeGrasse's decision because controlling precedent requires State "to provide a minimally adequate educational opportunity, but not ... to guarantee some higher, largely unspecified level of education"). The Campaign for Fiscal Equity is appealing to the New York Court of Appeals.

242. Hartzell v. Connell, 679 P.2d 35, 41 (Cal. 1984) (internal quotations omitted).

243. Jefferson, supra note 1, at 667; see also Ryan, supra note 223, at 148 (discussing Dewey's theories of education). 
their "worth and genius" regardless of "wealth, birth or other accidental condition." 244 Thus are the purposes of education laws "to provide an education adapted to the years, to the capacity, and the condition of every one, and directed to their freedom and happiness." 245

Such an egalitarian vision of society, directed towards people's freedom and happiness, well suits South Africa's needs. It is perhaps under this theory that the current school system's inequality ${ }^{246}$ seems most unjust and most contrary to the country's ideals and goals. While many American state court decisions focus more on the issue of adequacy than equality, ${ }^{247}$ some do emphasize notions of equality. In particular, the New Jersey Abbott cases have repeatedly struck down state education legislation, because it does not fund rich and poor schools equally. In Abbott v. Burke II, the state Supreme Court held that the state's education legislation was unconstitutional as applied to poorer urban schools. ${ }^{248}$ When the case returned to its docket a few years later, the Court struck down the state's Quality Education Act because of its "failure to assure parity of regular education expenditures between the special needs districts and the more affluent districts." 249

These decisions are directly applicable to a section 9 equality claim under South Africa's Constitution, and, importantly, further elucidate why the current education system fails to meet section 39 ideals. Equal education is important not just as its own end, but also because without it, future equality will be almost impossible to achieve in other sectors of life. Indeed, without more equal education, South African society will continue to resemble the world of apartheid. It remains one of the most unequal societies in the world. ${ }^{250}$ Thus, while the country's political changes are encouraging, the fact remains that everyday life has changed

244. Garrett Ward Sheldon, The Political Philosophy of Thomas Jefferson 63 (1991) (discussing Jefferson's theory of egalitarian education).

245. Jefferson, supra note 1 , at 147 (defending Virginia's new education laws); see also Ryan, supra note 223, at 181 (descrihing Dewey's theory that education ought not merely provide people with skills needed for jobs, but skills that would guarantee they have satisfying jobs); Sen, supra note 73, at 75 (discussing capability theory).

246. See supra Parts I \& II.B.3.

247. Reed, supra note 204, at 12; see also William E. Thro, To Render Them Safe: The Analysis of State Constitutional Provisions in Public School Finance Reform Litigation, 75 Va. L. Rev. I639, 1640-42, 1656 (1989) (discussing both litigation focusing on educational adequacy and suits focusing on equality).

248. Abbott v. Burke (Abbott II), 575 A.2d 359, 363 (N.J. 1990); see also Serrano v. Priest, 557 P.2d 929, 952-53, 957-58 (Cal. 1976) (holding that California public school financing violated equal protection provisions of state constitution by conditioning availability of scbool revenues upon district wealth, resulting in disparities in school revenue, and by making quality of education dependent upon level of district expenditure); Serrano v. Priest, 487 P.2d 1241, 1244 (Cal. 1971) (finding equal protection problem in school financing system which resulted in significant disparities between wealthy and poor school districts).

249. Abbott v. Burke (Abbott III), 643 A.2d 575, 576 (N.J. 1994).

250. See supra note 3 and accompanying text. 
little for the poorest South Africans. ${ }^{251}$ The chance to extend economic opportunity to communities that have never experienced it should serve as a strong justification for a Court holding that the government needs to do more to provide better schools.

\section{CONCLUSION}

South Africa's Constitution explicitly recognizes the right to education, and yet many South African schools fall far short of the constitutional requirement. The worst schools-mostly in predominantly black areas-lack the resources to provide students with the education they need to participate effectively in a democratic, capitalist society. Consequently, despite the past decade's remarkable political changes, many South Africans have little more chance to better their lot in life than they had under apartheid.

Notwithstanding serious budgetary concerns, the Constitutional Court should vindicate education rights for the nation's most deprived students. Given the Constitution's language in section 29, its commitment to democratic values in section 39 , and the Court's prior reasoning in Grootboom and TAC, the Court has solid legal arguments for requiring the government to provide better education. Due to the country's economic shortcomings and basic separation-of-powers concerns, the Court must leave room for the legislature to fashion realistic remedies. Nevertheless, following its earlier cases, it can do so while still promoting the constitutional values of dignity, equality, and freedom. Indeed, the Constitutional Court's very role in the South African system is to protect the most vulnerable by promulgating the ideals that the other government branches need to meet.

lt is for the promotion of these ideals that education is so vital in many societies, especially for a country like South Africa striving to right the wrongs of its past. Education is not merely an end in itself, but also a means to address many other social problems. Democratic ideals-which American case law can help elucidate-thus provide both a baseline for defining educational adequacy and a philosophical rationale for a Court decision requiring the government to provide its citizens with better schools.

251. See, e.g., Venter, supra note 160, 18-26 (arguing that South Africa's masses in townships and squatter camps will eventually rise up in frustration because their living conditions have changed little since the ANC government came to power). 